\title{
An illustrated key to the genera of Eumeninae from China, with a checklist of species (Hymenoptera, Vespidae)
}

\author{
Jiang-Li Tan', James M. Carpenter², Cornelis van Achterberg'
}

I Shaanxi Key Laboratory for Animal Conservation/Key Laboratory of Resource Biology and Biotechnology in Western China, Ministry of Education, College of Life Sciences, Northwest University, Xi'an, China 2 Division of Invertebrate Zoology, American Museum of Natural History, New York, NY, USA

Corresponding author: Jiang-Li Tan (tanjl@nwu.edu.cn)

Academic editor: A. Köhler | Received 30 November 2017 | Accepted 8 February 2018 | Published 2 March 2018

http://zoobank.org/FB0123FE-A8CB-4C35-98E7-A63076DE328D

Citation: Tan J-L, Carpenter JM, van Achterberg C (2018) An illustrated key to the genera of Eumeninae from China, with a checklist of species (Hymenoptera, Vespidae). ZooKeys 740: 109-149. https://doi.org/10.3897/zookeys.740.22654

\begin{abstract}
An illustrated key to the currently recognized genera of the subfamily Eumeninae (Vespidae) from China is presented together with a list of 267 species and subspecies, belonging to 51 genera. Nortozumia van der Vecht, 1937 is reported for the first time from China. Two replacement names are proposed for junior primary homonyms: Ancistrocerus rufofrustius Tan \& Carpenter, nom. n. replacing Ancistrocerus rufopictus (Kostylev) and Orientalicesa confasciatus Tan \& Carpenter, nom. n. replacing Orientalicesa unifasciatus (von Schulthess, 1934).
\end{abstract}

\section{Keywords}

homonym, illustrated key, new record, Oriental, Palaearctic

\section{Introduction}

Eumeninae or potter wasps are the largest subfamily of the Vespidae with 3773 valid species in 205 genera (Carpenter 1986; Zhou et al. 2011; Tan et al. 2015, 2018a; Pannure et al. 2016; Carpenter unpubl.). Eumeninae have a cosmopolitan distribution and are morphologically very diverse. The generic classification of Eumeninae is chaotic and has a troubled taxonomic history. The extreme splitting haphazardly

Copyright Jiang-LiTan et al. This is an open access article distributed under the terms of the Creative Commons Attribution License (CC BY 4.0), which permits unrestricted use, distribution, and reproduction in any medium, provided the original author and source are credited. 
pursued during much of the 20th century has contributed much to this current state (Hermes et al. 2014). Clearly, the situation with the generic classification will have to be rationalized by future synonymy of numerous taxa after their phylogeny is better known (Carpenter and Cumming 1985; Carpenter and Garcete-Barrett 2003; Hermes et al. 2014). The need for taxonomic work on Eumeninae is underlined by the lack of adequate and well-illustrated keys, both to genera and to species (Pannure et al. 2016). The few generic keys available concern one region or a country: Yamane (1990) revised the Japanese fauna of Eumeninae with a key to 18 genera, Carpenter and GarceteBarrett (2003) presented a key to the genera of Neotropical Eumeninae and Pannure et al. (2016) included a key to the 31 eumenine genera known from South India. We present the first illustrated key to genera of Eumeninae from a major area encompassing two faunal regions and the first complete key to genera of Chinese Eumeninae. It is a major step to facilitate the classification of Chinese Eumeninae. Nevertheless, the status of several genera remains problematical; only a combined approach using molecular, biological, and morphological data will make it possible to decide their taxonomic position.

The Chinese Eumeninae were first catalogued by Liu (1936-1937) resulting in a list of 57 species divided among nine genera. Unfortunately, his research stopped after his only revision (Pareumenes; Liu 1941). Lee (1982a, 1985) published the most recent key to the genera of Eumeninae in China, including only 25 genera (for 65 species and 13 subspecies). Finally, Zhou et al. (2011) listed 45 genera present in China and included 172 species and 50 subspecies. Several scattered papers have been published on Chinese Eumeninae, but a thorough inventory is lacking (Zhou et al. 2012, 2013; Li and Chen 2014a, 2014b, 2015, 2016a, 2016b; You et al. 2013; Ma et al. 2016, 2017; Nguyen and Xu 2014; 2015; 2017; Yeh and Lu 2017; Tan et al. 2018a). The illustrated key to the genera of Chinese Eumeninae presented here includes 51 genera and the checklist contains 267 species and subspecies in total. One genus (Nortozumia van der Vecht, 1937) is reported as new to China. Two replacement names are proposed for junior primary homonyms: Ancistrocerus rufofrustius Tan \& Carpenter, nom. n. replacing Ancistrocerus rufopictus (Kostylev) and Orientalicesa confasciatus Tan \& Carpenter, nom. n. replacing Orientalicesa unifasciatus (von Schulthess, 1934).

\section{Material and methods}

Specimens were collected by hand net or with Malaise traps. The studied specimens are deposited in the collections of College of Life Sciences, Northwest University, Xi'an (NWUX); Northwest A\&F University Entomological Museum, Yangling, Shaanxi (NWAY); Zhejiang University Hymenoptera Museum, Hangzhou (ZJUH); General Station of Forest Pest Management, State Forestry Administration, Shenyang (GSFA); American Museum of Natural History, New York (AMNH); Naturalis Biodiversity Center, Leiden (RMNH); Museum national d'Histoire naturelle, Paris (MNHN); and Senckenberg Deutsches Entomologisches Institut, Müncheberg (SDEI). 
Morphological terminology follows Carpenter and Cumming (1985), Yamane (1990), and Carpenter and Garcete-Barrett (2003). Observations and descriptions were made with an Olympus SZX11 stereomicroscope and fluorescent lamps. Photographic images were made with Keyence VHX-5000 digital microscope (NWUX, Xi' an), Olympus SZX 12 stereomicroscope with analySIS Soft Imaging System software (RMNH, Leiden), and Microptics-USA/Visionary Digital photomicrographic system, developed by Roy Larimer, multiple layers stacked using Helicon Focus (AMNH, New York).

\section{Key to genera of Eumeninae from China}

1 Tergum I more or less petiolate, slender and its apical half parallel-sided or slightly narrowed posteriorly (1a); tergum I usually at least twice as long as wide (but in e.g., Pseudozumia slightly longer than wide); tergum II twice maximum width of tergum $I$ in dorsal view, but approx. $1.5 \times$ in Pseudozumia

- $\quad$ Tergum I robust and its apical half widened posteriorly (1aa); tergum I much less than twice as long as wide; tergum II at most twice as wide as tergum I......... 18
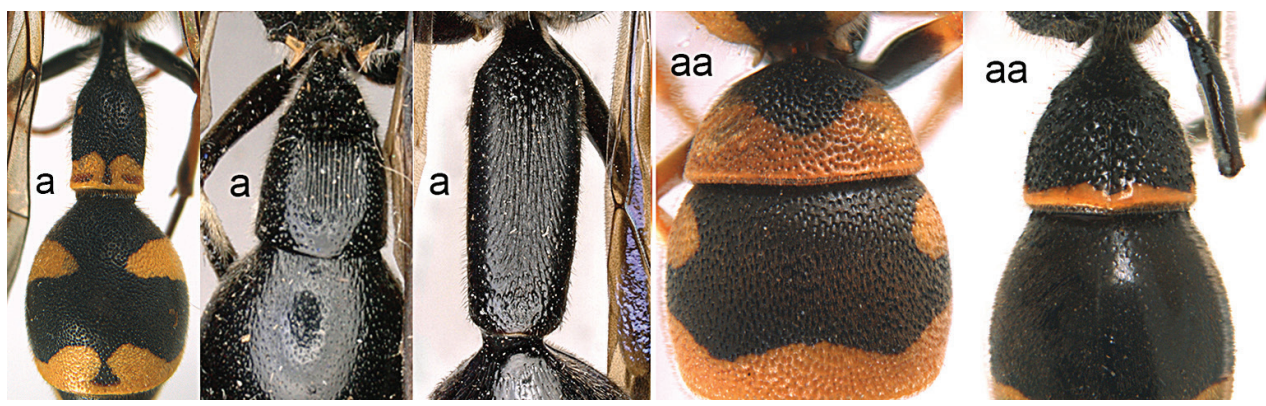

Figure I. Metasomal terga I-II, dorsal view: a Eumenes m. mediterraneus (Kriechbaumer) (left 1), Pseudozumia indica (de Saussure) (left 2), Calligaster cyanoptera de Saussure (middle) aa Antepipona deflenda lepeletieri (Blüthgen) (right 2), Symmorphus foveolatus (Gussakovskij) (right1).

$2 \quad$ Middle tibia with two spurs (2a) 3

$-$ Middle tibia with one spur (2aa) 5

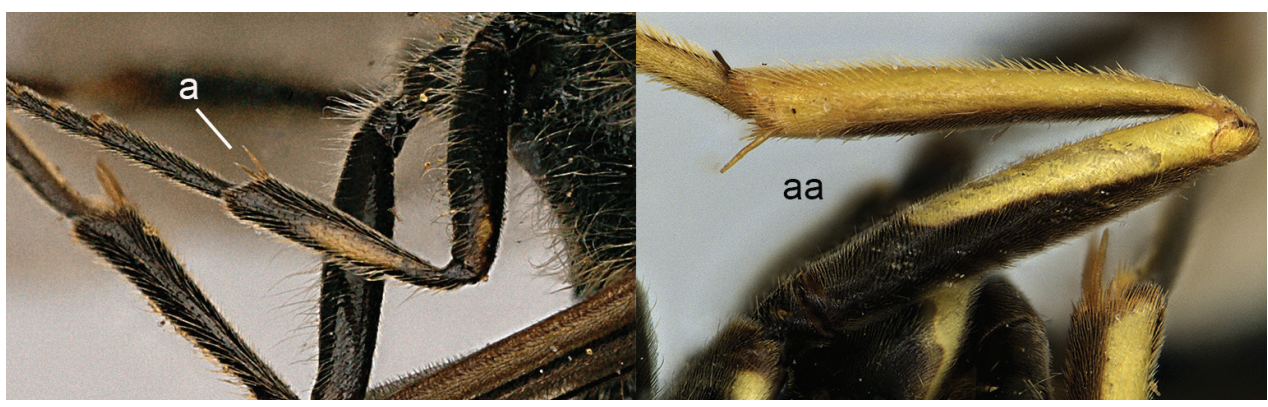

Figure 2. Part of middle leg: a Discoelis zonalis (Panzer) aa Pseumenes depressus annulatus van der Vecht. 
3 Propodeum with valvula distinctly protruding, elongate and rectangular (3a), orifice acutely pointed dorsally (3b) Zethus Fabricius

- $\quad$ Propodeum with valvula not protruding (3aa), orifice rounded dorsally (3bb) 4

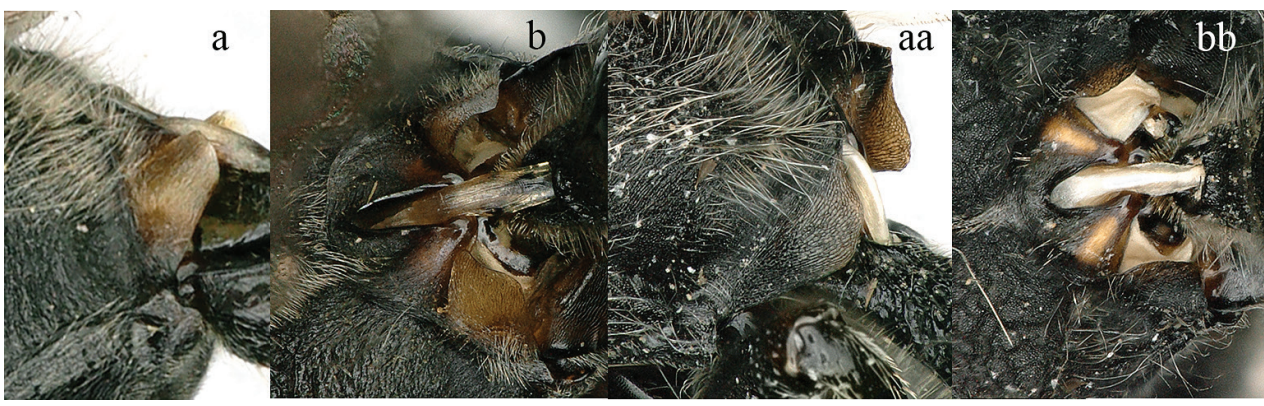

Figure 3. Part of propodeum lateral view (a, aa) and caudal view (b, bb): a, b Zethus velamellatus Tan aa, bb Discoelis zonalis (Panzer).

$4 \quad$ Maxillary palpus 3-segmented (4a); tergum I more than twice as long as wide, longitudinally striate (4b); tegula posteriorly acute (4c).... Calligaster de Saussure

- $\quad$ Maxillary palpus 4-segmented (4aa); tergum I less than twice as long as wide, punctate $(4 \mathrm{bb})$; tegula posteriorly truncate $(4 \mathrm{cc})$..... Discoelius Latreille

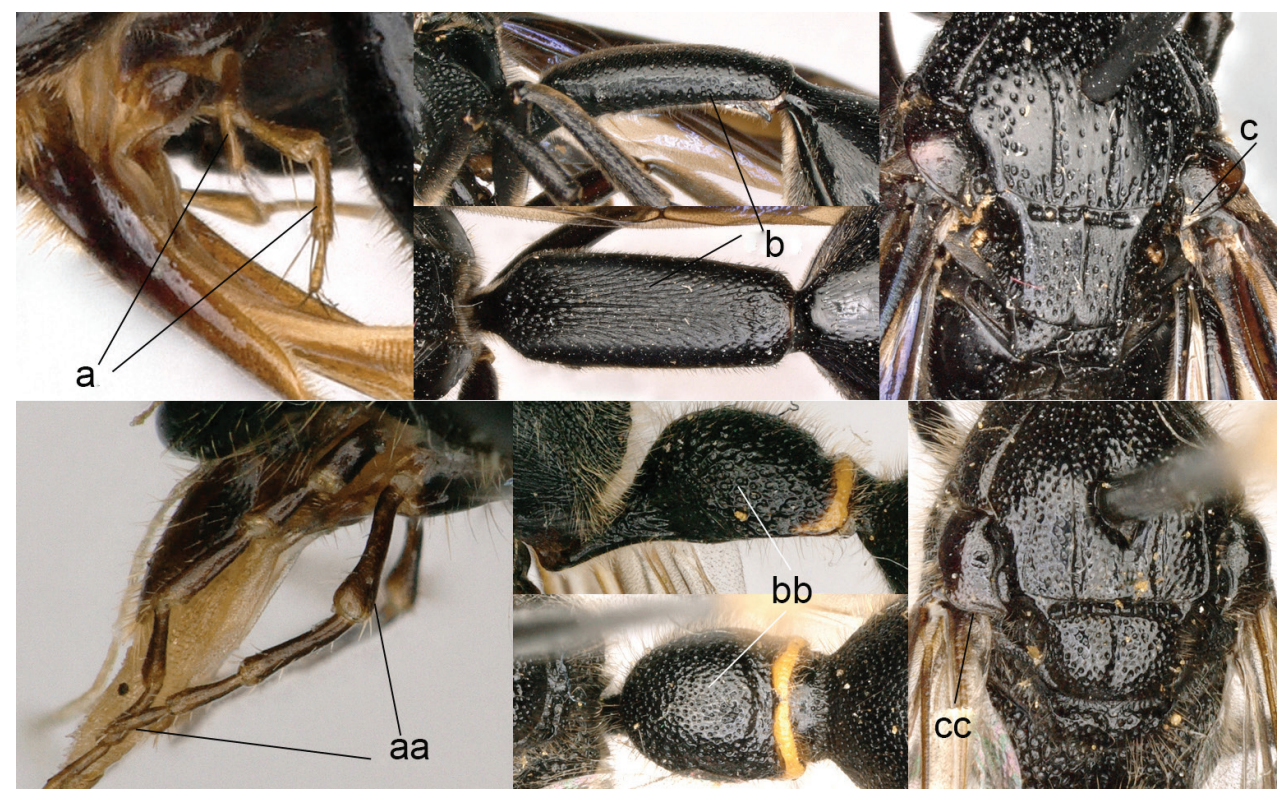

Figure 4. Labial palpi (a, aa) and metasomal segment I (b, bb): c, cc part of mesosoma, showing tegula: a-c Calligaster cyanoptera de Saussure aa-cc Discoelis zonalis (Panzer). 
5 Propodeal valvula relatively short, rounded, submarginal carina distinctly protruding (5a); frons distinctly longer than clypeus; second submarginal cell narrow anteriorly, vein 1-M and vein 2-M meeting almost at right angle (5b).... Propodeal valvula elongate, rectangular, submarginal carina not protruding (4aa); frons shorter than clypeus; second submarginal cell wide anteriorly, vein $1-\mathrm{M}$ and vein $2-\mathrm{M}$ meeting at obtuse angle (5bb)

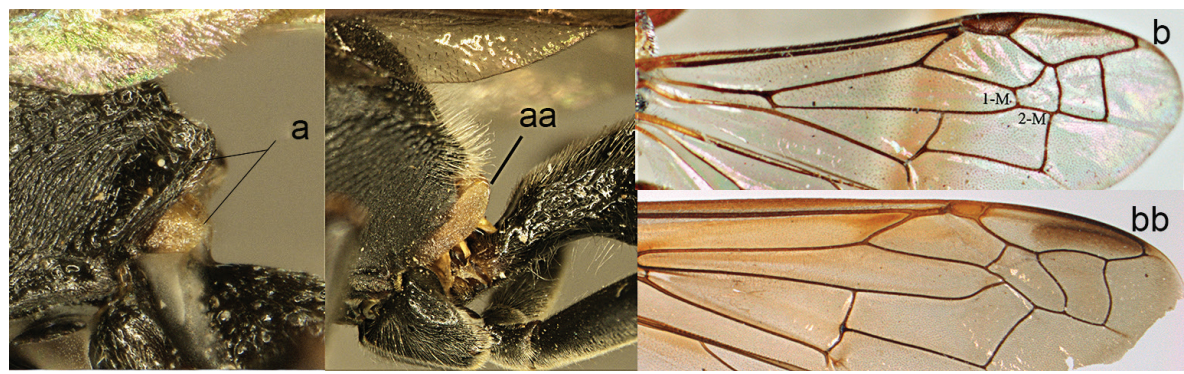

Figure 5. Propodeum (a, aa) and part of forewing (b, bb): a Leptomicrodynerus tieshengi Giordani Soika b Labus spiniger de Saussure (right upper) aa Coeleumenes sp. (middle) bb Delta campaniforme esuriens (Fabricius).

Female with fovea anterior to mid-ocellus (6a); metanotum monodentiform mesally (6d); metasomal petiole abruptly swollen apically in lateral view (6c); tegula not exceeding parategula posteriorly (6b); anterior face of pronotum smooth (6e) Labus de Saussure

- $\quad$ Female without fovea on vertex (6aa); metanotum obtuse mesally (6dd); metasomal petiole not conspicuously swollen in lateral view (6cc); tegula more or less exceeding parategula posteriorly (6bb); anterior face of pronotum distinctly punctuate laterally (6ee)

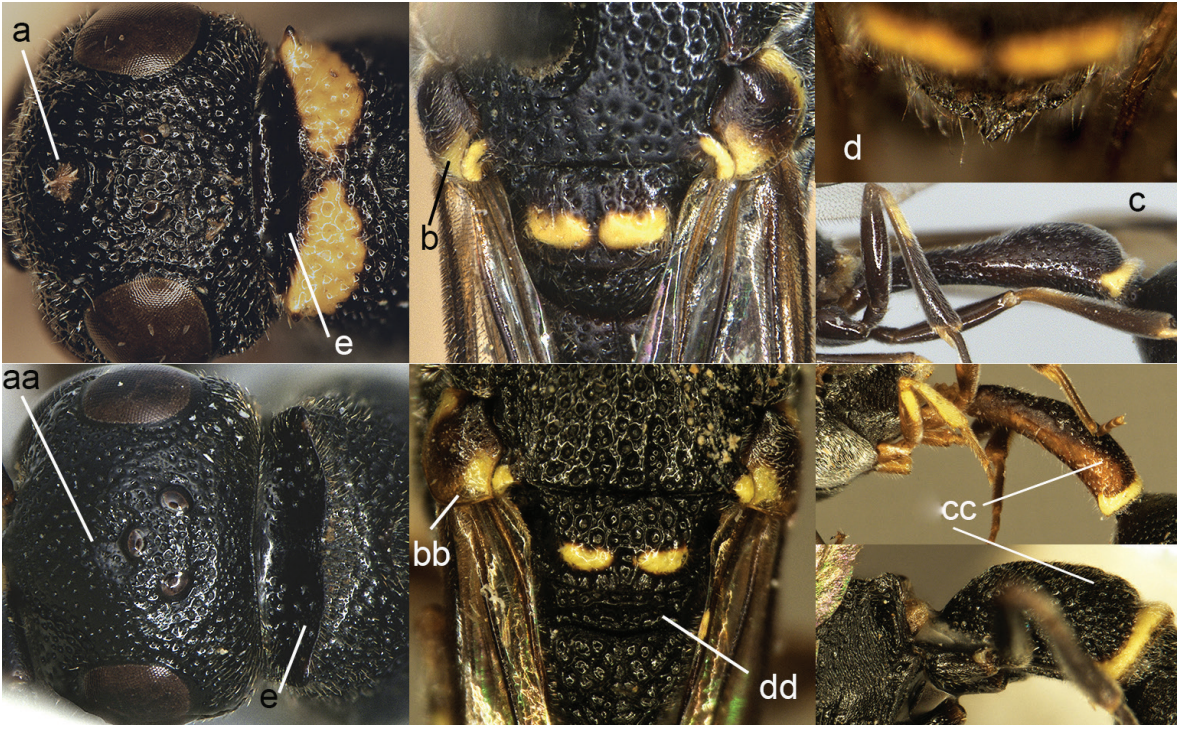

Figure 6. Head and pronotum (a, e, aa, ee), part of mesonotum in dorsal view (b, bb, dd), metanotum magnified (d), and metasomal segment I in lateral view (c, cc): a-e Labus spiniger (de Saussure) aa, ee, lower cc Leptomicrodynerus tieshengi Giordani Soika bb, dd, upper cc Cyrtolabulus suavis van der Vecht. 
7 Mesoscutum distinctly longer than wide (7a), apical margin of tergum I wider than half width of TII (7b); parategula short, almost absent, tegula distinctly exceeding parategula $(7 \mathrm{c})$

Leptomicrodynerus Giordani Soika

- $\quad$ Mesoscutum distinctly wider than long (7aa); apical margin of tergum I narrower than half width of tergum II (7bb); parategula normal, tegula slightly exceeding parategula $(7 \mathrm{cc})$

Cyrtolabulus van der Vecht

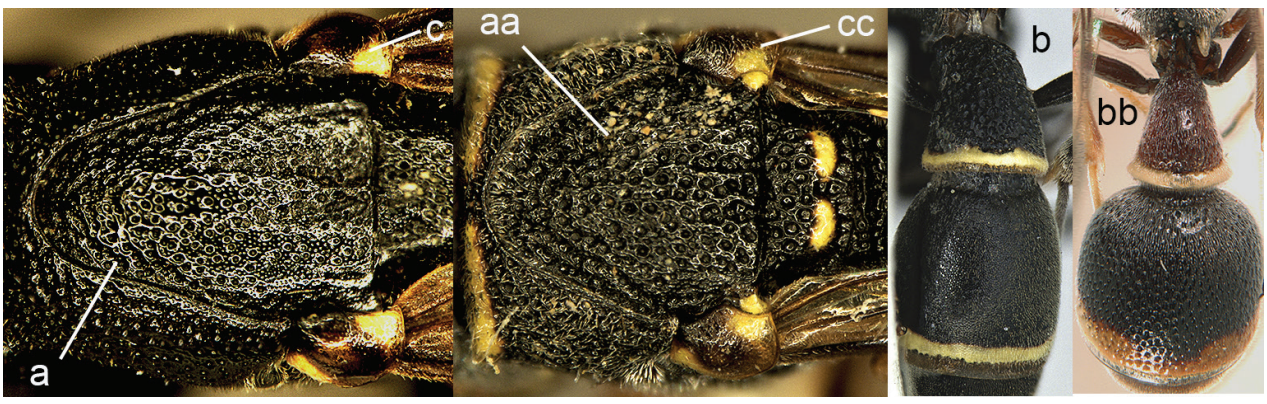

Figure 7. Mesosoma (a, c, aa, cc) and metasoma (b, bb). a-c Leptomicrodynerus tieshengi Giordani Soika aa, cc Cyrtolabulus suavis van der Vecht bb Cyrtolabulus exiguus (de Saussure).

8 Propodeum dorsally with elongate fovea from which a carina runs to orifice, usually with dentiform projections above valvulae (8a); axillary fossa narrower than long, slit-like (8b); tegula with narrow posterior lobe which about equals parategula posteriorly $(8 \mathrm{c})$

- $\quad$ Propodeum without fovea or dentiform projections (8aa); axillary fossa oval, broader than long (8bb); tegula short, convex and not equalling parategula posteriorly $(8 \mathrm{cc})$, or long, with narrow posterior lobe which surpasses parategula posteriorly

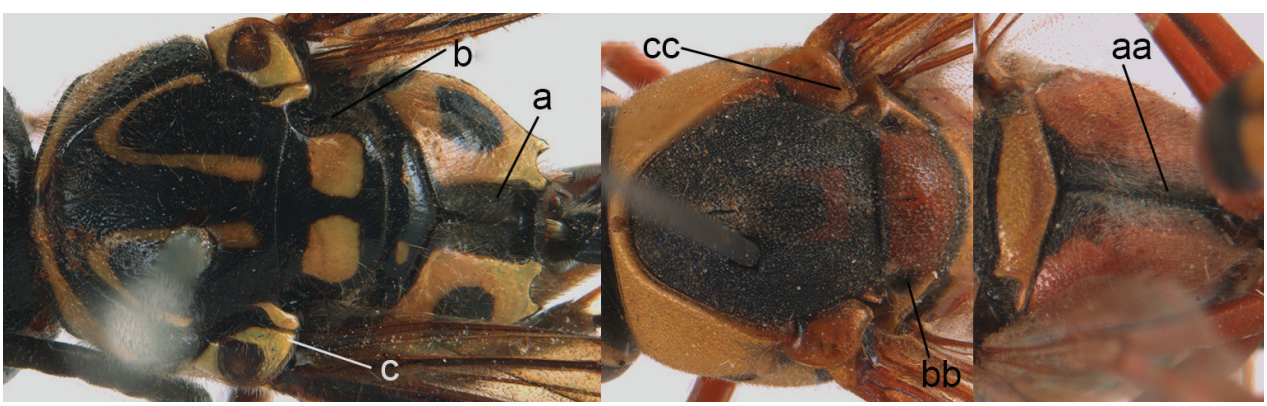

Figure 8. Mesosoma, dorsal view. a-c Pseumenes d. depressus (de Saussure) aa-cc Delta campaniforme gracile (de Saussure). 
9 Mesepisternum with epicnemial carina present $(9 \mathrm{a})$
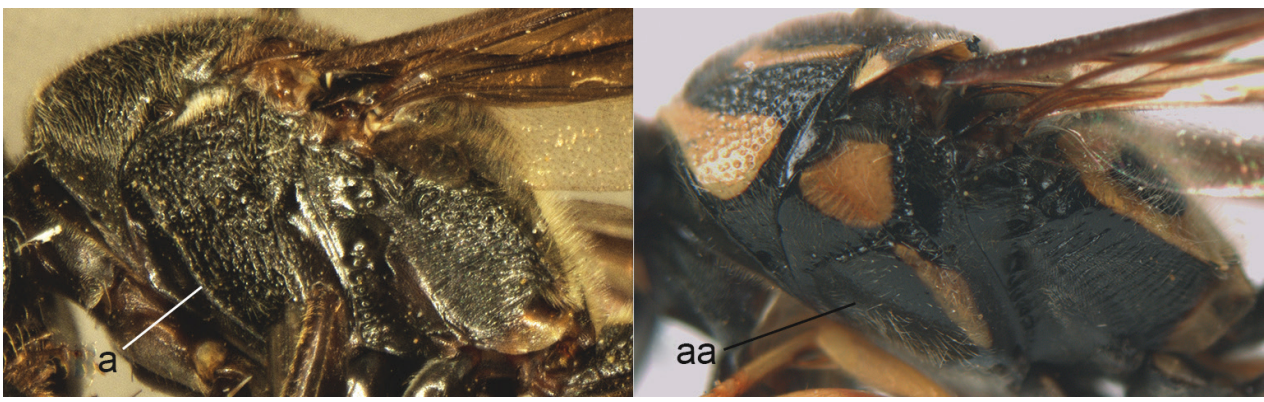

Figure 9. Mesosoma, lateral view. a Nortozumia sp. aa Pseumenes d. depressus (de Saussure).

10 Metasomal petiole with transverse carina basally (10a, a'). 11

- $\quad$ Metasomal petiole not carinate (10aa, aa')

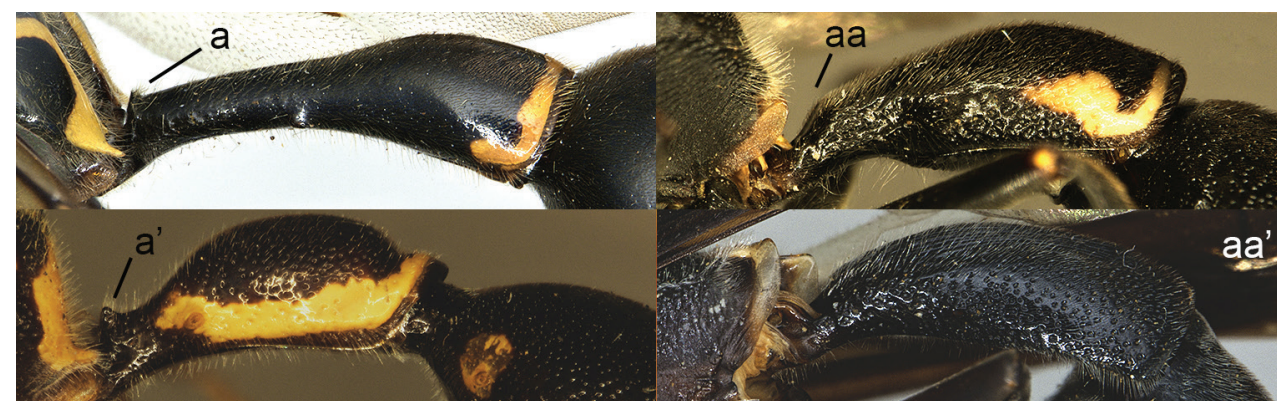

Figure 10. Metasomal segment I in lateral view. a Ectopioglossa s. samariensis (Giordani Soika) a' Nortozumia pulchella (Smith) aa Coeleumenes sp. aa' Pseudozumia indica paulonotata Giordani Soika.

11 Tergum I with its lateral margins fused ventrally; sternum I reduced to posterior crescentic sclerite (11a); [mesonotum and propodeum smooth between fine punctures].

Ectopioglossa Perkins

- $\quad$ Tergum I with lateral margins not meeting ventrally, sternum I visible along entire petiole length (11aa) Nortozumia van der Vecht (new record)

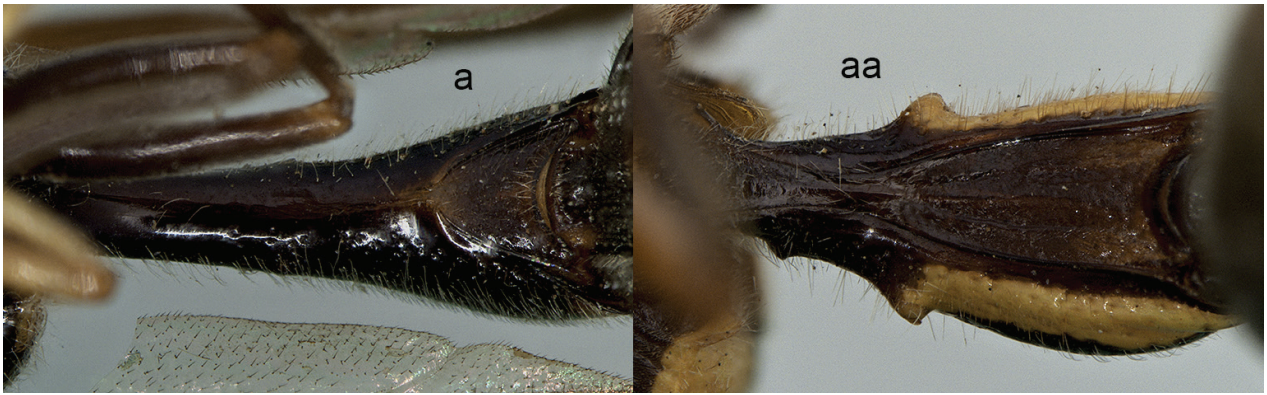

Figure II. Metasomal segment I, ventral view. a Ectopioglossa s. samariensis (Giordani Soika) aa Nortozumia pulchella (Smith). 
12 Mesoscutum with a pair of prescutellar longitudinal groove (12a); forewing with parastigma longer than pterostigma (12b); sternum I irregularly rugose posteriorly, with rugae running in longitudinal direction (12c) .......Pseudozumia de Saussure - Mesoscutum without prescutellar longitudinal groove (12aa); forewing with parastigma shorter than pterostigma (12bb); sternum I smooth basally, its posterior two thirds transversely striate or smooth $(12 \mathrm{cc})$....... Coeleumenes van der Vecht

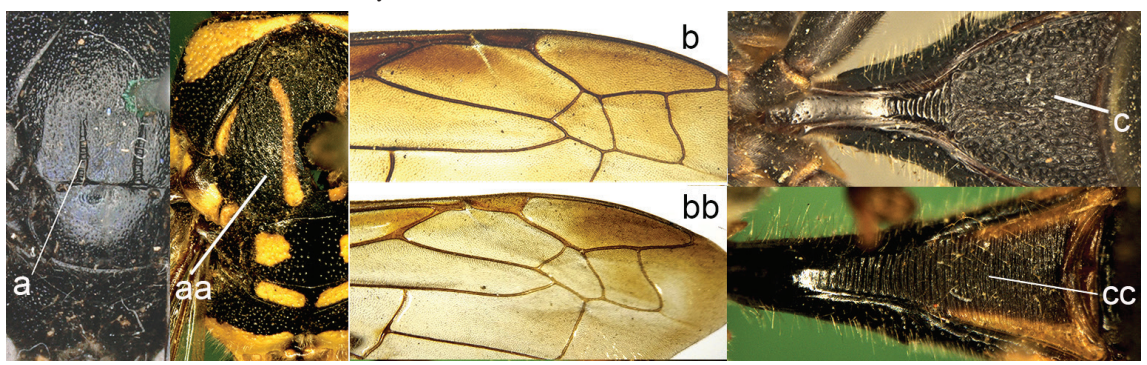

Figure 12. Part of dorsal mesosoma (a, aa), part of forewing (b, bb) and ventral metasomal segment I (c, cc). a Pseudozumia i. indica (de Saussure) b Pseudozumia indica borneana Giordani Soika c Pseudozumia sp. aa-cc Coeleumenes impavidus (Bingham).

13 Forewing with parastigma longer than pterostigma (13a); sternum I gradually widened backwards with regular transverse striae (13b); female with cephalic fovea (13c); hind tibia with number of short spines on its outside (13d) ......

Pareumenes de Saussure

- $\quad$ Forewing with parastigma shorter than pterostigma (13aa); sternum I narrower basally, more or less fused with tergum I, posteriorly short, triangular and without ruga (13bb); female without cephalic fovea (13cc); hind tibia without spines on its outside $(13 \mathrm{dd})$

Pseumenes Giordani Soika

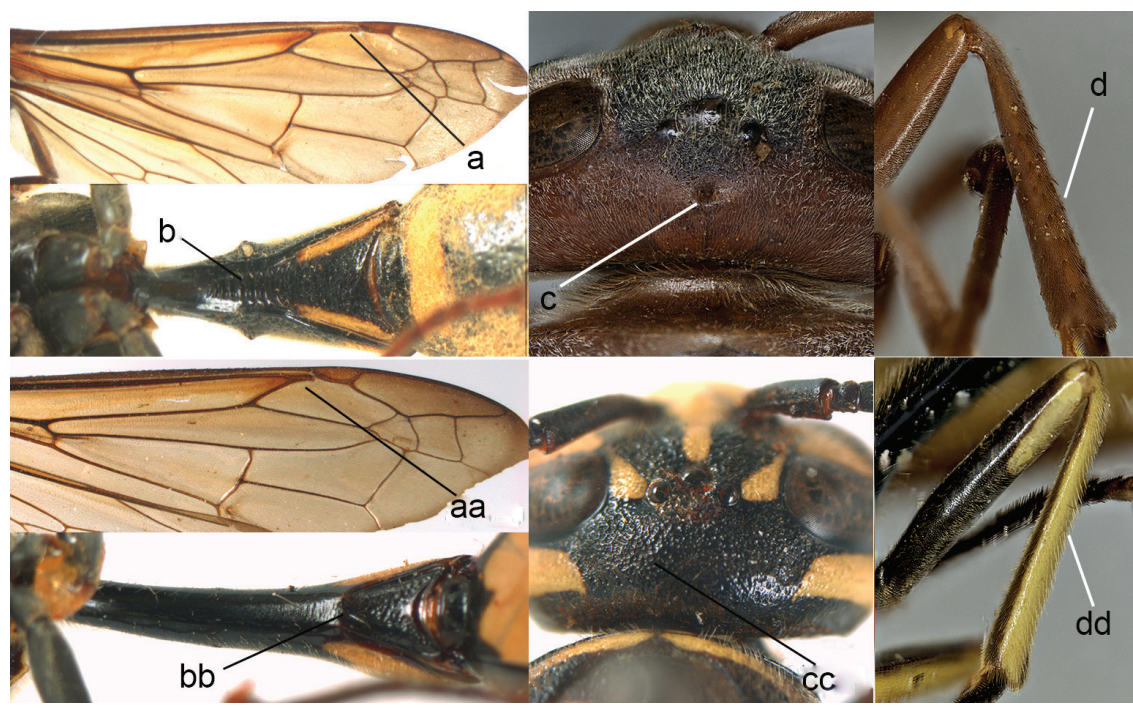

Figure 13. Forewing (a, aa), metasomal sternum I (SI) (b, bb), head in dorsal view (c, cc) and hind tibia (d, dd). a-b Pareumenes quadrispinosus conjunctus Liu c, $\mathbf{d}$ Pareumenes s. sansibaricus (von Schulthess) aa-cc Pseumenes $d$. depressus (de Saussure); dd. Pseumenes depressus annulatus van der Vecht. 
14 Tergum I impunctate or with only a few small punctures (14c); propodeum inclining posteriorly into a slope (14a); tergum II without lamella separated by preapical thickening, sometimes with pale border (14b).

- $\quad$ Tergum I with dense, coarse punctation (14cc); propodeum less inclined posteriorly (14aa); tergum II with apical lamella more or less separated from disc by preapical thickening (14bb)

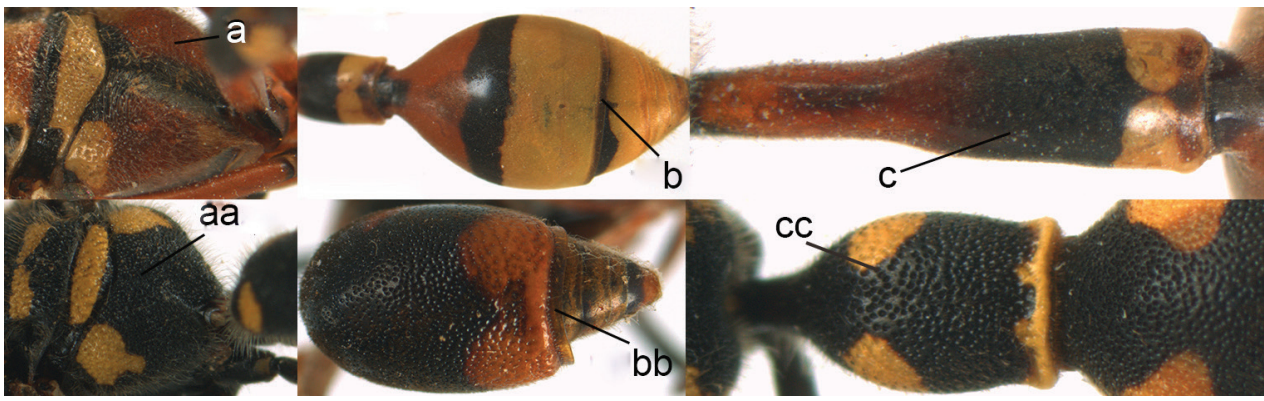

Figure I4. Propodeum (a, aa), metasomal tergum II (TII) (b, bb) and metasomal tergum I (TI) (c, cc). a-c Delta campaniforme esuriens (Fabricius) aa, cc Eumenes c. coarctatus (Linnaeus) bb Eumenes kiangsuensis Giordani Soika.

15 Clypeus apically rounded (15a); temple in dorsal view as long as eye (15b)... Katamenes Meade-Waldo - $\quad$ Clypeus apically truncate or emarginated (15aa); temple in dorsal view shorter than eye (15bb)
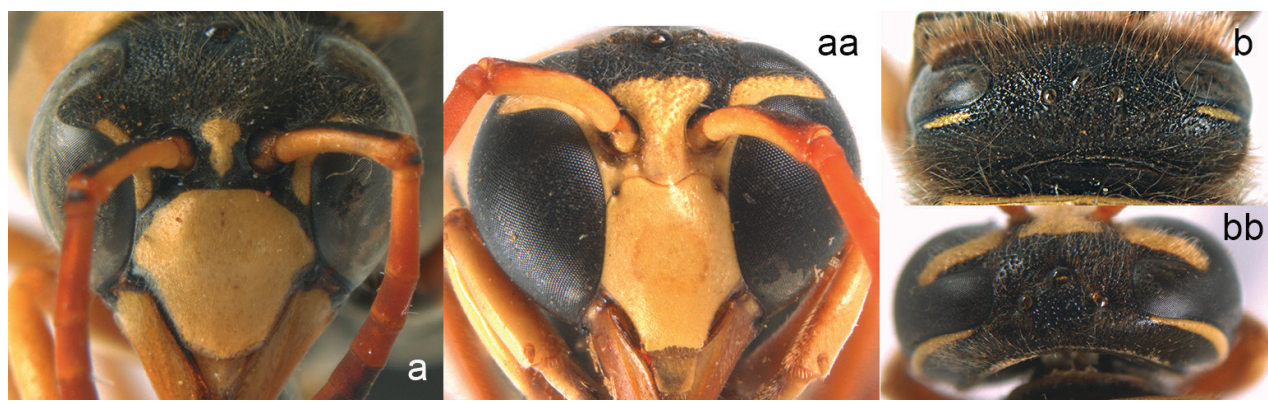

Figure I5. Head in frontal (a, aa) and dorsal view (b, bb). a, b Katamenes sesquicinctus (Lichtenstein) aa, bb Delta campaniforme gracile (de Saussure). 
16 Tergum I slightly longer than mesosoma, with section after spiracles shorter than section before spiracles (16a); male: terminal sternum with a longitudinal groove (16b).

Delta de Saussure

- $\quad$ Tergum I much longer than mesosoma, with section after spiracles longer than section before spiracles (16aa); male: terminal sternum without groove (16bb)

Phimenes Giordani Soika

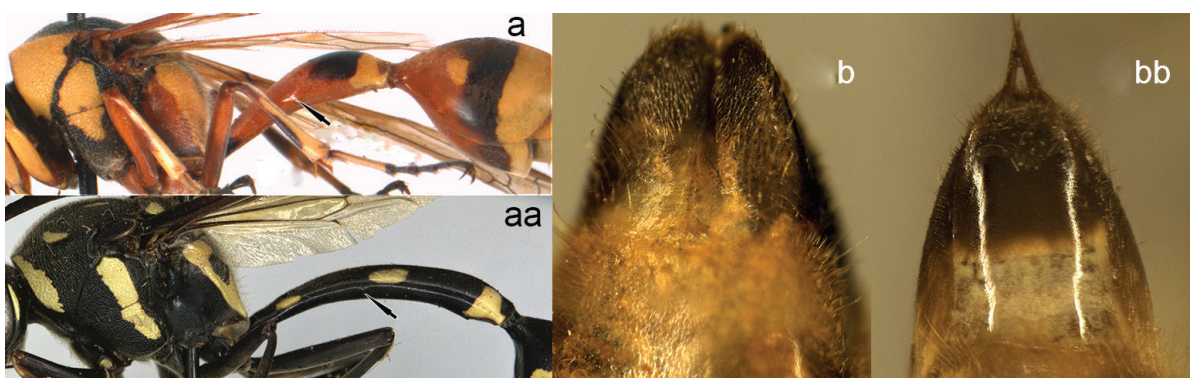

Figure 16. Mesosoma and part of metasoma (a, aa), terminal sternum of male (b, bb). a, b Delta campaniforme gracile (de Saussure), arrow = spiracle aa, $\mathbf{b b}$ Phimenes f. flavopictus (Blanchard).

17 Pronotum with pretegular carina absent (17b); parastigma of forewing shorter than half of pterostigma (17a); female: apical margin of clypeus emarginated (17c); propodeum lateral margin rounded, without distinct border with posterior face; male: apical antennal segment medium-sized and curved (17d).

Eumenes Latreille

- $\quad$ Pronotum with pretegular carina present (17bb); parastigma of forewing longer than half of pterostigma (17aa); female: apical margin of clypeus truncated (17cc); propodeum lateral side distinctly separated from its posterior face; male: apical antennal segment small and straight $(17 \mathrm{dd})$ Oreumenes Bequaert
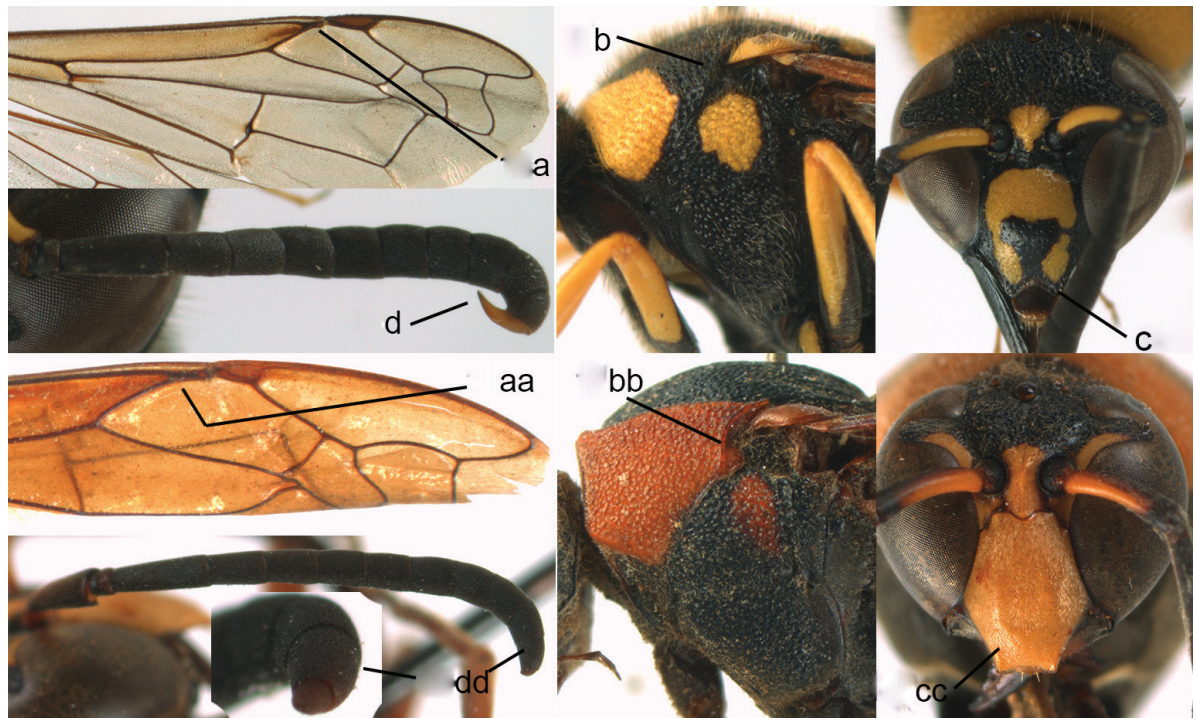

Figure 17. Forewing (a, aa), mesosoma in lateral view (b, bb), head in frontal view (c, cc) and antenna (d, dd). a-d Eumenes $c$. coarctatus (Linnaeus) aa-dd Oreumenes decoratus (Smith). 
18 Tegula evenly rounded posteriorly and usually not reaching apex of parategula (18a); male antenna apically spiralled (18b) .

- Tegula protruding posteriorly, emarginate or truncate adjoining parategula (18aa); male antenna apically hooked or simple (18bb)

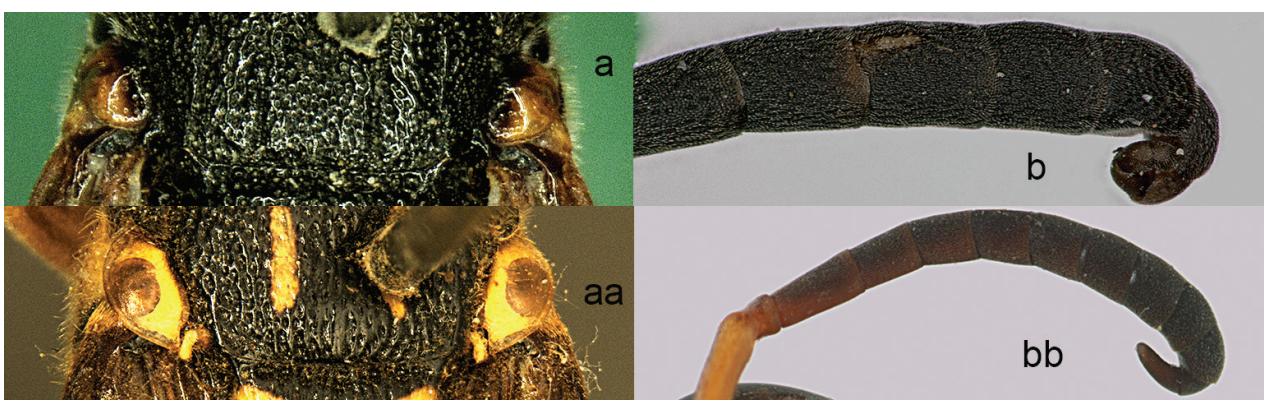

Figure 18. Part of mesosoma (a, aa) and antennae (b, bb). a Onychopterocheilus mochii (Giordani Soika) b Pterocheilus p. phaleratus (Panzer) aa Stenodyneriellus guttulatus (de Saussure) bb Euodynerus d. dantici (Rossi).

19 Labial palpi 3-segmented, in female segment II and III both broadly flattened, fringed with setae, forming a psammophore (19a); sterna II-V in male usually with central apical brush (19b).

- Labial palpus 4-segmented, in female cylindrical, without psammophore (19aa); sterna II-V in male usually without central apical brush (19bb) ....21

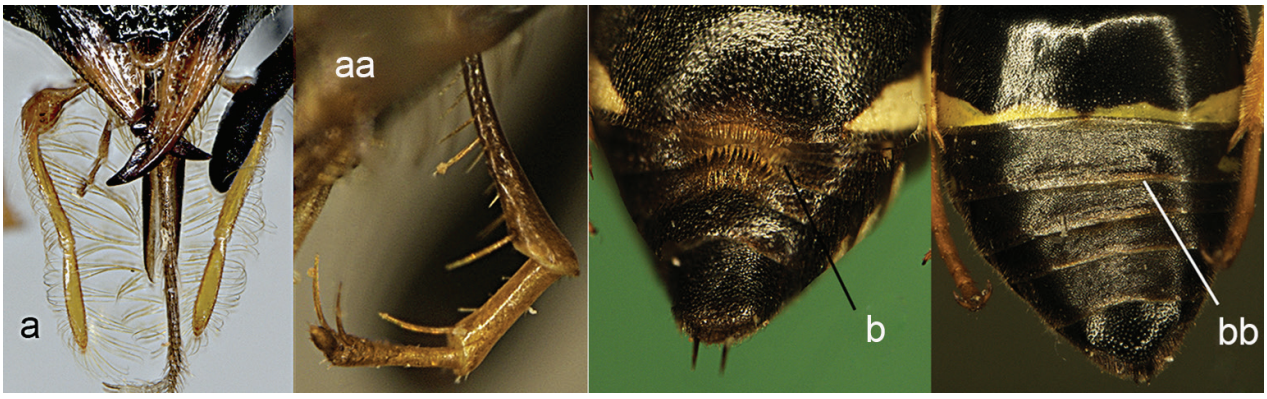

Figure 19. Part of mouthparts showing labial palpus (a, aa) and metasomal sterna (SII-VII) of male (b, bb). a Onychopterochilus mochii (Giordani Soika) b Pterocheilus p. phaleratus (Panzer) aa-bb Odynerus albopictus (de Saussure). 
20 Maxillary palpus 5- (20a) or 6- (20a') segmented; female: labial palpus segment II thick basally, segment II, III not curved (20b); male: mandible with penultimate tooth often without deep excision, and axis of penultimate tooth is at an oblique angle relative to main axis of mandible and approximately parallel to axis of apical tooth (20c); body $<9 \mathrm{~mm}$

Pterocheilus Klug

- $\quad$ Maxillary palpus 6-segmented (20aa); female: labial palpus segment II and III slender, flat and curved (20bb); male: mandible with distance between second and third tooth broad (20cc) or deeply and broadly excised, and axis of penultimate tooth is at approximately a right angle relative to the main axis of the mandible and relative to the apical tooth (20cc'); body $>10 \mathrm{~mm}$

Onychopterocheilus Blüthgen

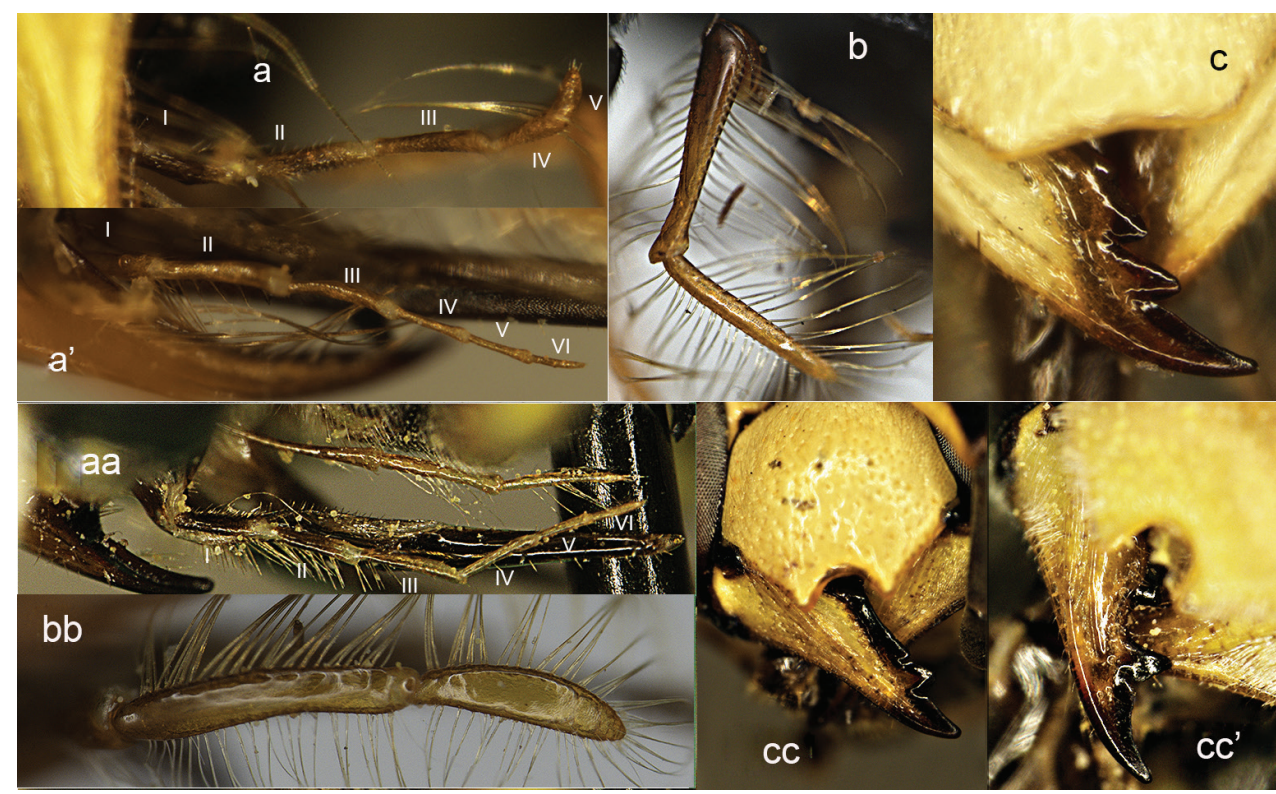

Figure 20. Maxillary palpus (a, a' and aa), labial palpus of female (b, bb) and mandibles of male (c, cc, cc'). a-c Pterocheilus p. phaleratus (Panzer) a' Pterocheilus c. chobauti Dusmet; aa-bb Onychopterocheilus mochii Giordani Soika cc Onychopterocheilus pallasii (Klug) cc' Onychopterocheilus sp. 
21 Propodeum with lateral carinae well developed (21a); female without cephalic foveae (21b); vertex weakly longitudinally rugose posteriorly (21b); temples and mesosoma with very fine pubescence; male sterna II-VI with conspicuous fringe of setae (21c)

Tropidodynerus Blüthgen

- $\quad$ Propodeum with lateral carinae weak or absent (21aa); female with cephalic foveae; vertex not rugose; temples and mesosoma with long setae (21bb); male sterna without fringe of setae $(21 \mathrm{cc})$

Odynerus Latreille

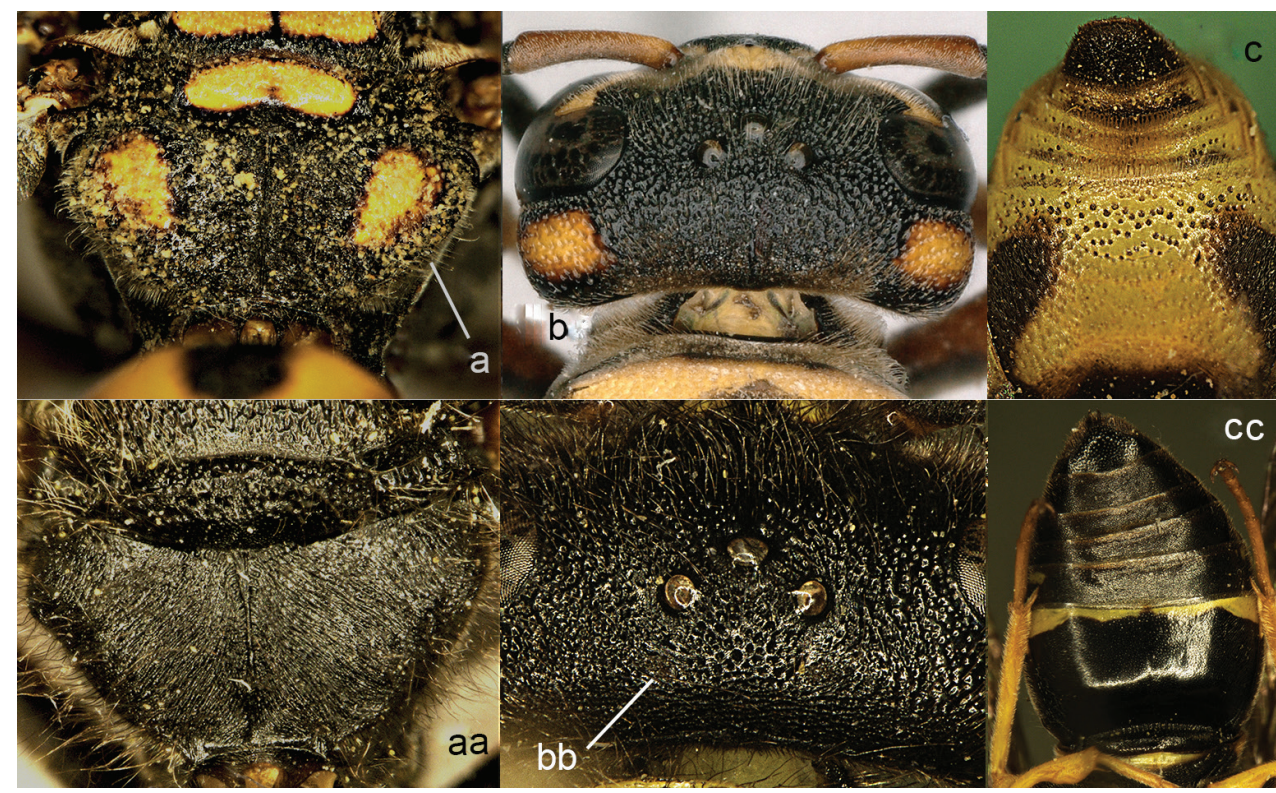

Figure 2I. Propodeum (a, aa), head in dorsal view (b, bb) and sterna $(\mathbf{c}, \mathbf{c c})$. a, b Tropidodynerus $f$. flavus (Bingham) c Tropidodynerus hostis (Nurse) aa-cc Odynerus albopictus (de Saussure).

22 Anterior face of pronotum with two close and deeply impressed pits, which may be approximated, or with series of elongate foveae (22a); tegula broad, wider than long, not surpassing parategula (except Jucancistrocerus) (22b); propodeum valvula bilamellate (with submarginal carina produced into pointed lamella apically and valvula enlarged and free posteriorly from submarginal carina) (22c) .................................................................. 23

- $\quad$ Anterior face of pronotum without deep pits or foveae (except punctures) (22aa, aa'); submarginal carina, propodeum valvula and tegula variable .... 28 


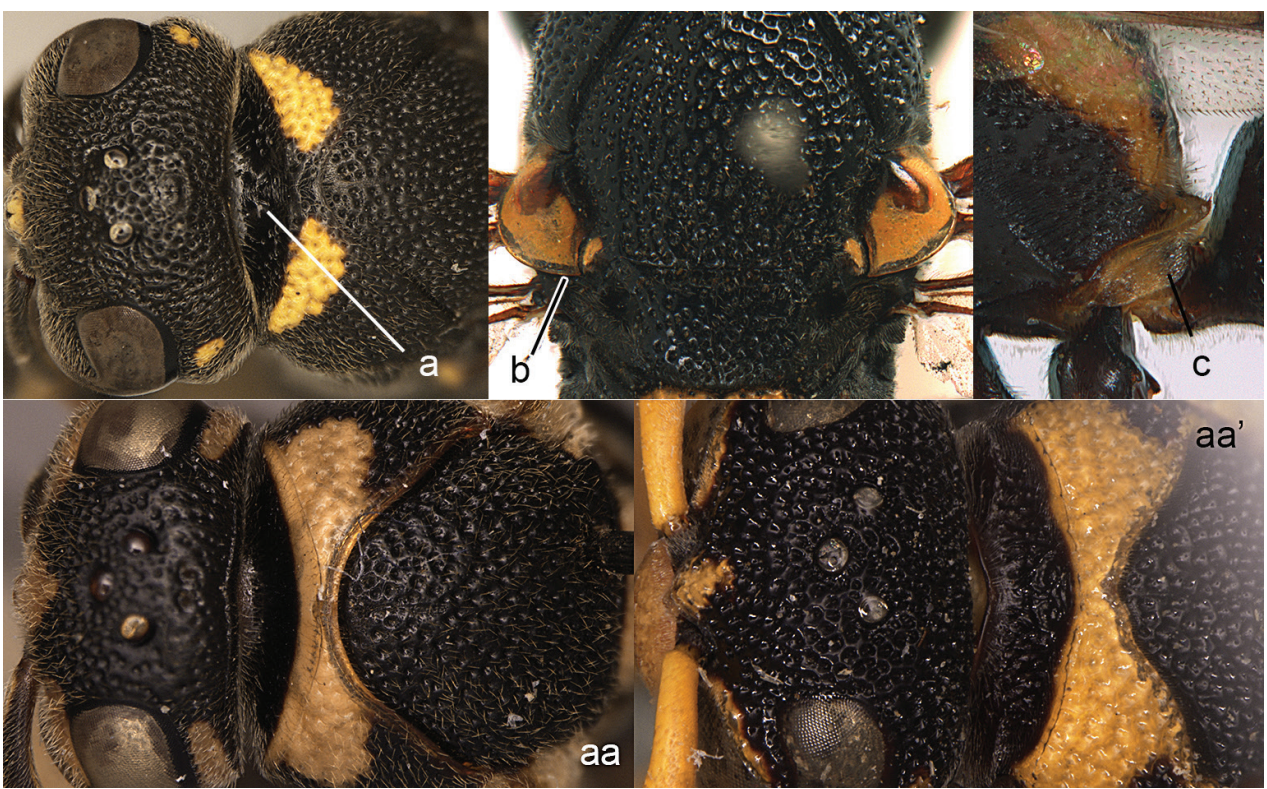

Figure 22. Head and pronotum in dorsal view (a, aa, aa'), part of mesosoma in dorsal view (b) and propodeum lateral view (c). a, c Stenodynerus c. chinensis (de Saussure) b Stenodynerus frauenfeldi (de Saussure) aa Stenodyneriellus sp. aa' Brachyodynerus magnificus (Morawitz).

23 Tergum I with two transverse carinae (23a) or with one (23a') ................24

- Tergum I without transverse carinae (23aa) ......................................27

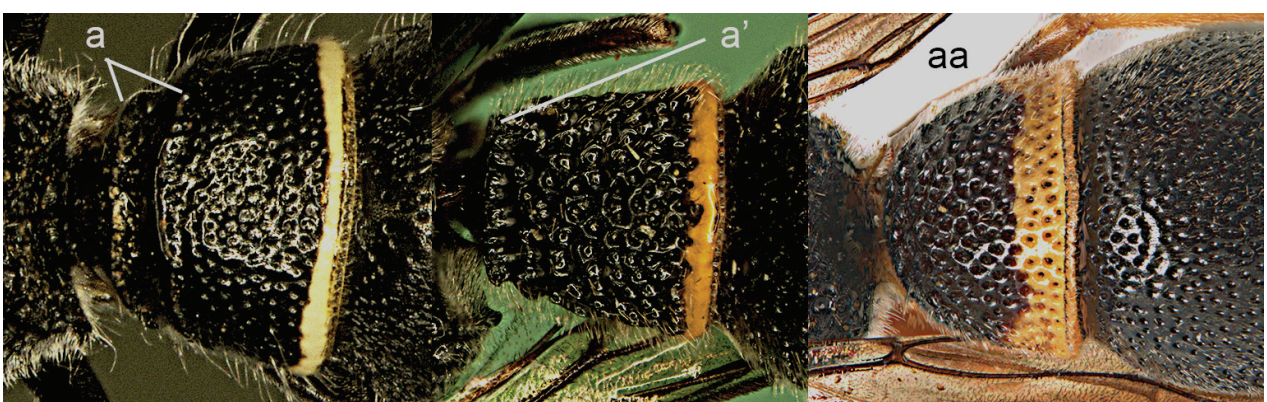

Figure 23. Metasomal tergum I. a Subancistrocerus sichelii (de Saussure) a' Pseudonortonia abbreviaticornis Giordani Soika aa Stenodynerus chinensis (de Saussure).

24 Tegula densely punctate, sieve-like, surpassing parategula posteriorly (24a); propodeal dorsum without extending horizontal area (24b); pretegular carina absent (24c); [carina of tergum I indistinct in some species]

Jucancistrocerus Blüthgen

- $\quad$ Tegula usually finely punctate (24aa); propodeal dorsum extending horizontally, forming shelf-like area behind metanotum (24bb); pretegular carina present $(24 \mathrm{cc})$ 


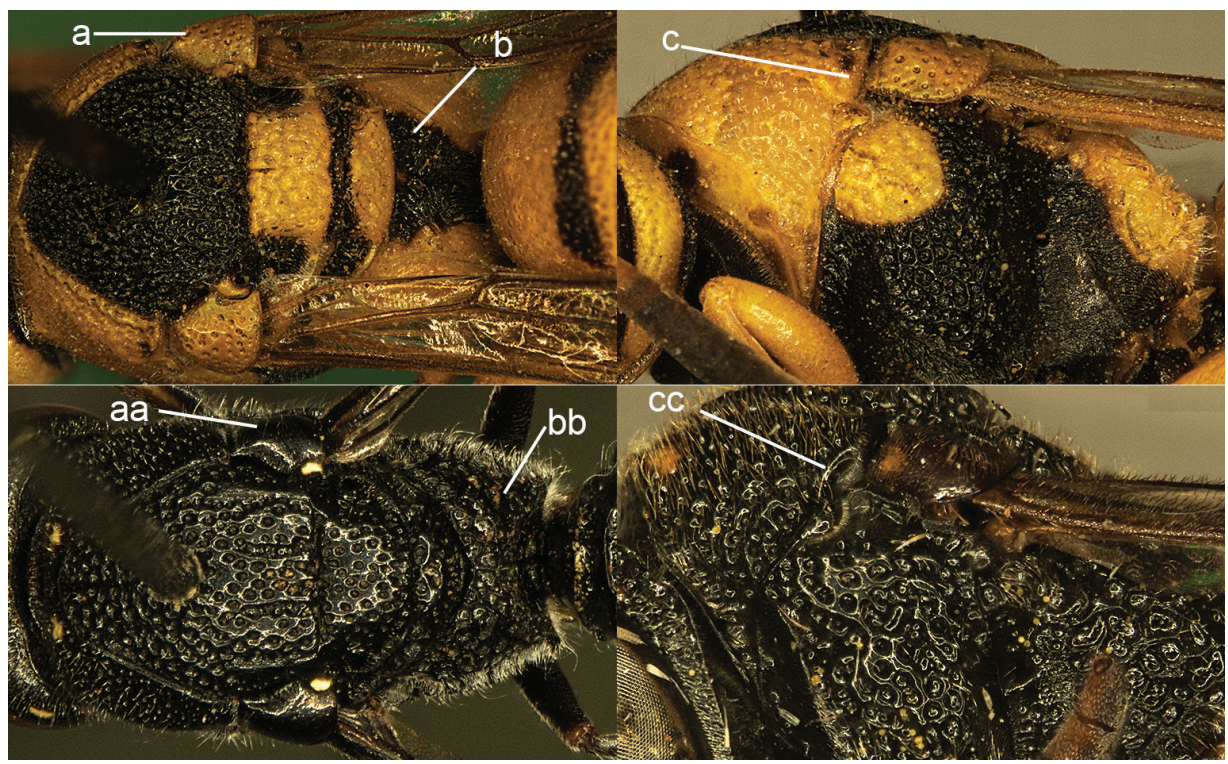

Figure 24. Mesosoma in dorsal view (a, b, aa, bb) and in lateral view (c, cc). a-c Jucancistrocerus (Eremodynerus) atrofasciatus (Morawitz) aa-cc Pseudonortonia abbreviaticornis Giordani Soika.

25 Tergum I with two carinae, tergum wider than long in dorsal view, both carinae relatively close near each other (25a)........Subancistrocerus de Saussure - $\quad$ Tergum I with one (25aa) or two carinae (25aa'); if with two carinae, then tergum I longer than wide in dorsal view, more or less petiole-like and distance between both carinae relatively large

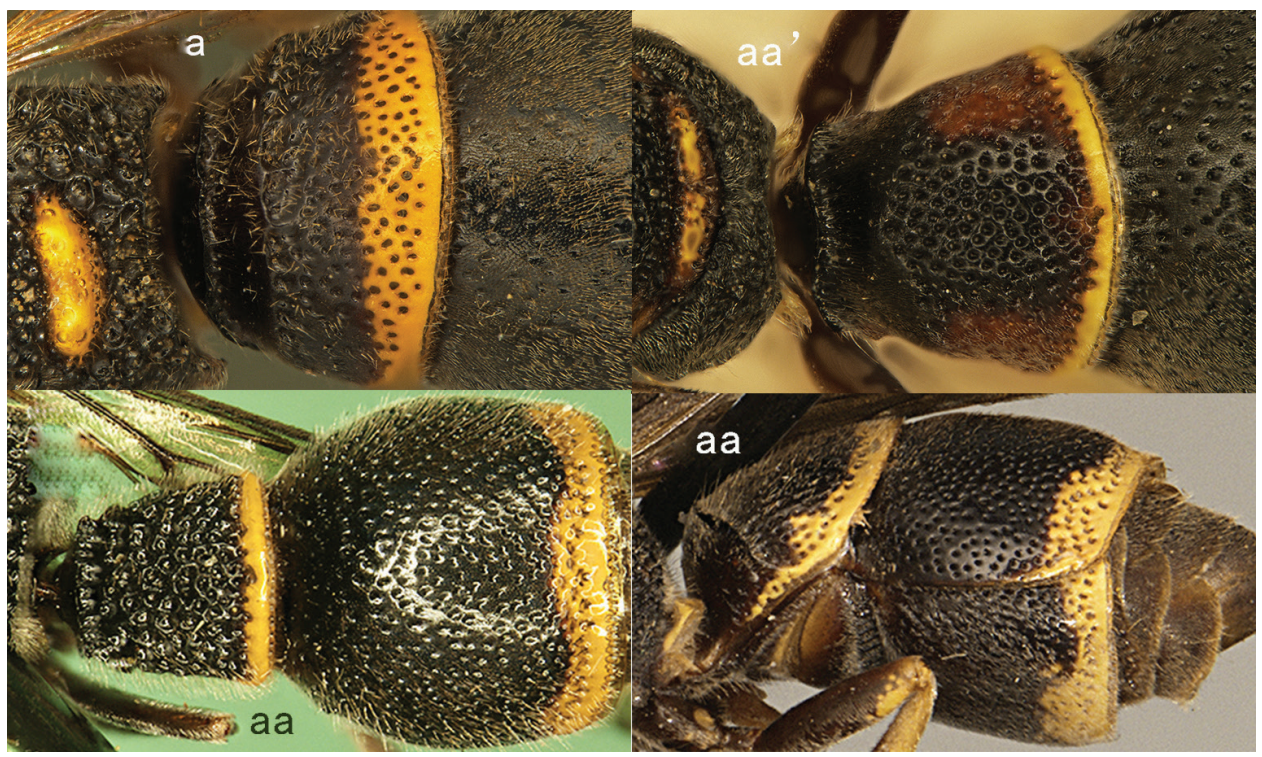

Figure 25. Metasomal tergum I in dorsal view. a Subancistrocerus domesticus aa (left). Psendonortonia abbreviaticornis Giordani Soika aa (right). Parancistrocerus samarensis (von Schulthess) aa' Pseudonortonia sp. 
26 Anterior face of pronotum with foveae separated (26a); tergum II usually smooth basally, forming an acarinarium (26b); metasoma sessile, tergum I nearly as wide as tergum II (26b')

Parancistrocerus Bequaert

- $\quad$ Anterior face of pronotum with contiguous foveae (26aa); tergum II ridged basally, not forming an acarinarium; tergum I in dorsal view longer than wide, tergum II much wider than tergum I (26bb) Pseudonortonia Giordani Soika

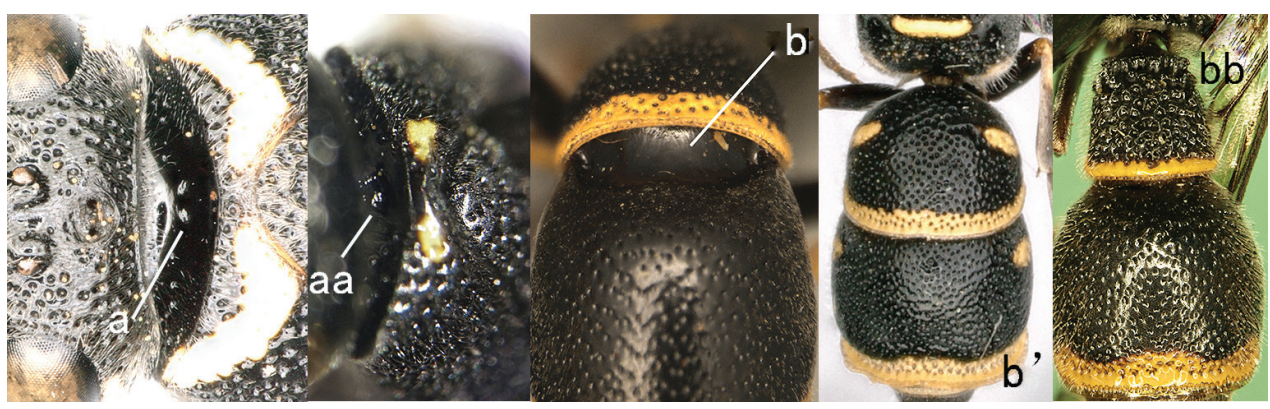

Figure 26. Anterior face of pronotum (a, aa); metasomal segments I and II (b, b', bb). a, b' Parancistrocerus toltecus b Parancistrocerus samarensis (von Schulthess) bb Pseudonortonia abbreviaticornis Giordani Soika.

27 Tergum I relatively short, gradually widened, with its lateral sides divergent in dorsal view (27a); vertex strongly depressed, forming an acute triangle with face (27b, arrowing part); in female, apical margin of clypeus truncated and with two longitudinal carinae (27c); anterior face of pronotum with foveae coalesced $(27 \mathrm{~b})$

Paraleptomenes Giordani Soika

- $\quad$ Tergum I relatively long, roughly parallel-sided in dorsal view (27aa); vertex normal, not forming an acute triangle with face (27bb); apical margin of clypeus emarginate and without carina $(27 \mathrm{cc})$; anterior face of pronotum with foveae separated (22a). [Note: if tergum I of Parancistrocerus spp. has an indistinct transverse carina, then it is difficult to separate them from Stenodynerus; Parancistrocerus spp. usually have an acarinarium on tergum II basally and tergum I more or less lengthened medially in dorsal view, while Stenodynerus spp. have tergum II ridged basally and tergum I medio-dorsally without elongation] Stenodynerus de Saussure 


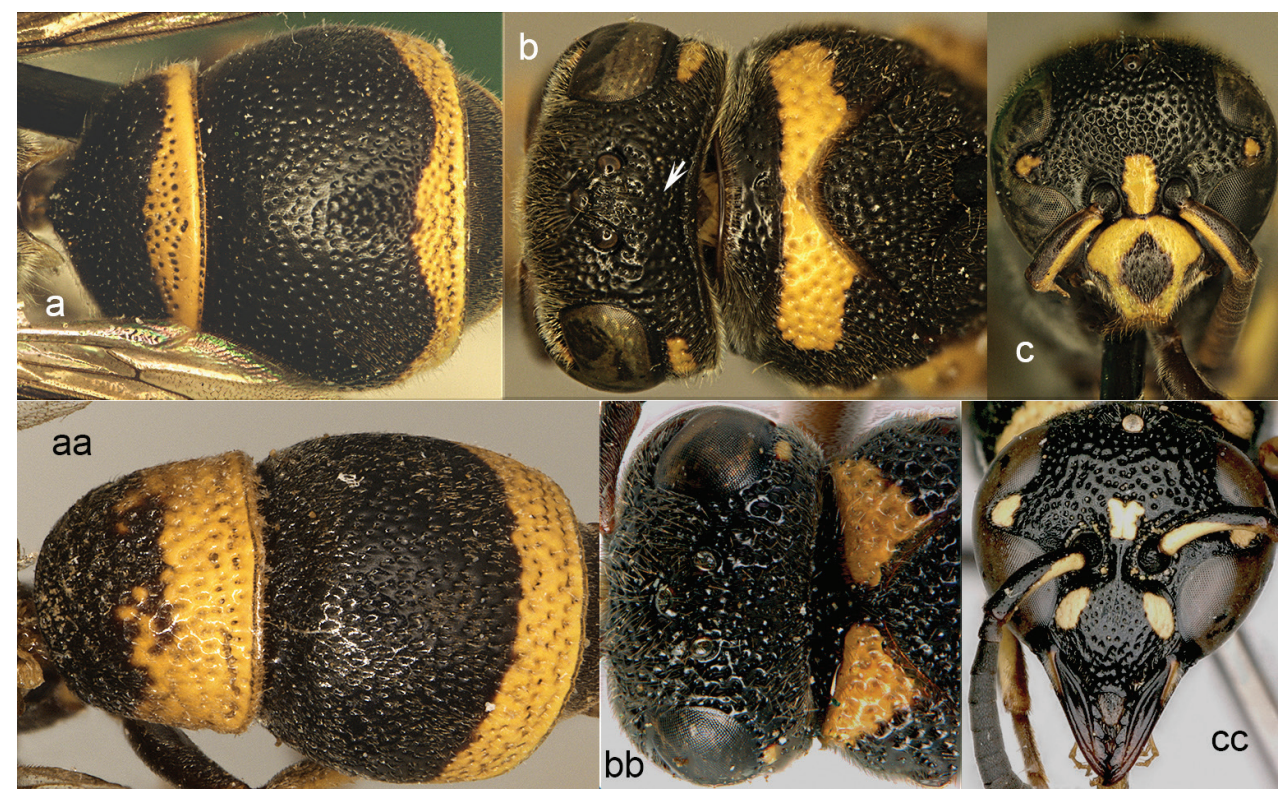

Figure 27. Metasoma in dorsal view (a, aa), head and pronotum in dorsal view (b, bb, white-arrow pointing to the depression) and in frontal view (c, cc). Paraleptomenes kosempoensis (von Schulthess) aa-cc Stenodynerus chinensis (de Saussure).

28 Tergum I transversely carinate (28a) or horizontal and vertical faces of tergum clearly separated (Pararrhynchium, 28a').

- $\quad$ Tergum I evenly curved, without transverse carina (28aa)

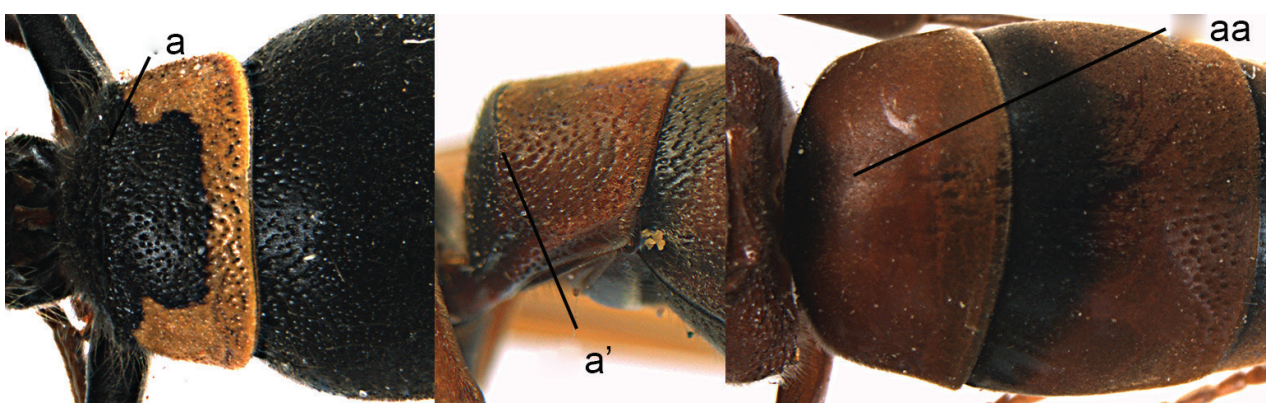

Figure 28. Metasomal tergum I (TI) in dorsal view (a, aa) and in lateral view (a'). a Ancistrocerus parietinus (Linnaeus) a' Pararrhynchium ornatum sauteri (Schulthess) c Rhynchium carnaticum (Fabricius). 
29 Tergum I with broad medio-longitudinal furrow posterior to transverse carina (29a); notauli clearly indicated (29b); male antenna simple apically (29c)

Symmorphus Wesmael - $\quad$ Tergum I without medio-longitudinal furrow (29aa); notauli absent or nearly so (29bb); male antenna hooked apically (29cc)......
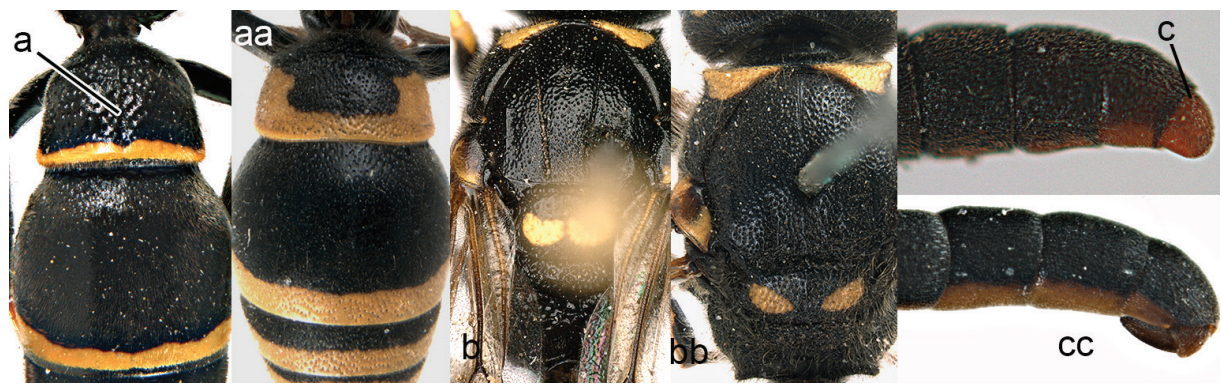

Figure 29. Metasomal terga I-II (a, aa) and mesosoma (b, bb) in dorsal view, distal segments of antenna (c, cc). a, c Symmorphus bifasciatus (Linnaeus) b Symmorphus elegans aa-cc Ancistrocerus parietinus (Linnaeus).

30 Parastigma of forewing with more than half the length of pterostigma, measured along posterior part, often nearly equal (30a)

- $\quad$ Parastigma half the length of pterostigma or less, measured along posterior part (30aa)
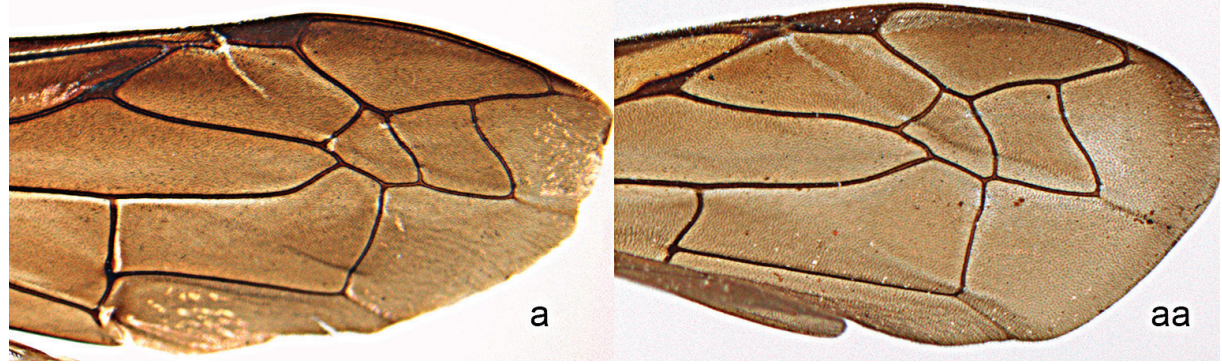

Figure 30. Forewing. a Orancistrocerus a. aterrimus (de Saussure) aa Pararrhynchium o. ornatum (Smith).

31 Tergum II with well-developed apical lamella (31a)

\section{Lissodynerus Giordani Soika}

$-$ Tergum II lacking an apical lamella (31aa)

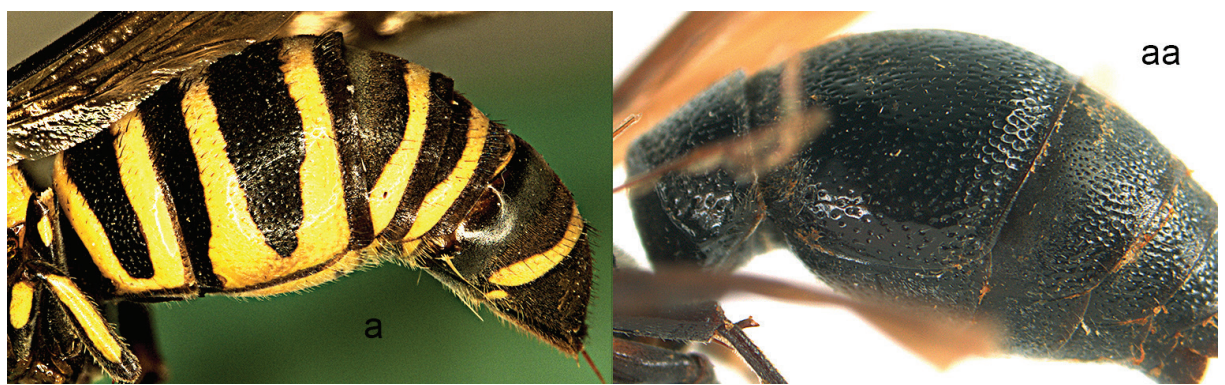

Figure 3I. Metasoma in lateral view. a Lissodynerus s. septemfasciatus (Smith) aa Orancistrocerus a. aterrimus (de Saussure). 
32 Clypeus wide ventrally and slightly emarginated medio-ventrally (32a); male: terminal sternum without teeth basally (32b).... Orancistrocerus van der Vecht - $\quad$ Clypeus narrower ventrally and deeply emarginated medio-ventrally (32aa); male: terminal sternum with $2-3$ teeth basally (32bb)

\section{Archancistrocerus Giordani Soika}

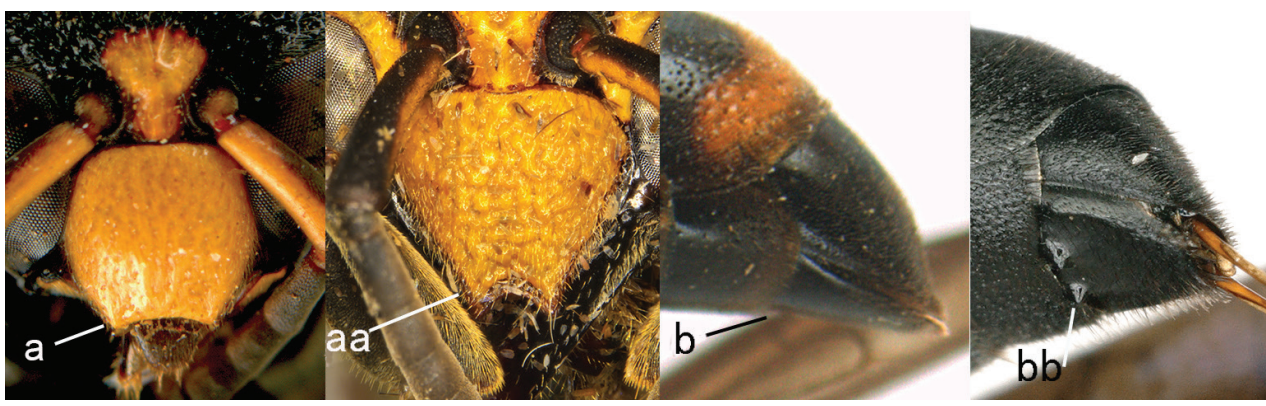

Figure 32. Clypeus (2 left) and distal part of male metasoma in lateral view (2 right). a, b Orancistrocerus drewseni opulentissimus (Giordani Soika) aa Archancistrocerus diffinis Giordani Soika, holotype bb Archancistrocerus $\mathrm{sp}$.

33 Axillary fossa narrower than long, slit-like (33b); humeri ("shoulder") rounded (33a); propodeal dorsum strongly extending horizontally, forming shelflike area behind metanotum (33c)

Pararrhynchium de Saussure

- $\quad$ Axillary fossa oval, broader than long (33bb); humeri angular or pointed (33aa); propodeal dorsum slightly extending behind metanotum, below level of metanotum $(33 \mathrm{cc})$...... Ancistrocerus Wesmael

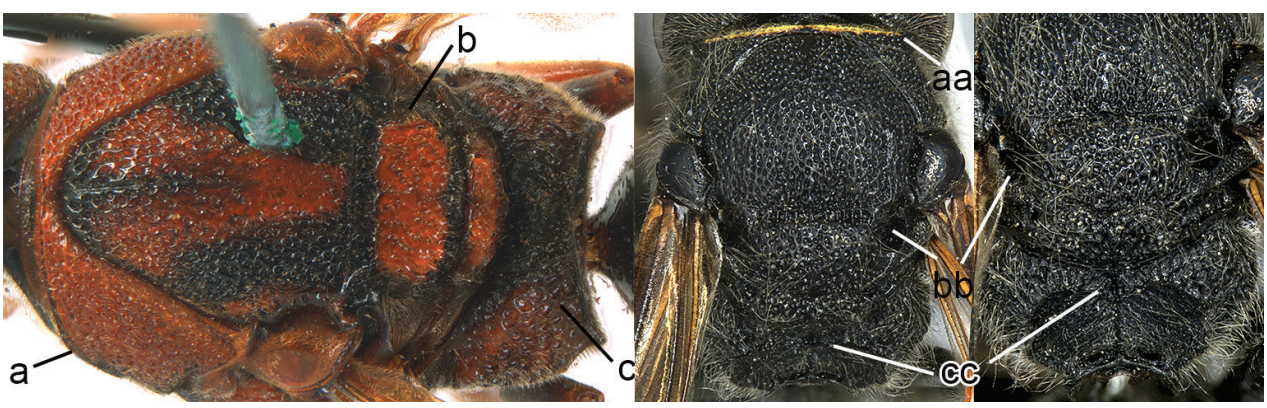

Figure 33. Mesosoma in dorsal view (left and middle) and dorso-caudal view (right). a-c Pararrhynchium ornatum sauteri (Schulthess) aa-cc Ancistrocerus trifasciatus shibuyai (Yasumatsu). 
34 Metanotum with serrate bilobed ridge (34a, a')

- $\quad$ Metanotum low toothed (34aa), including blunt or rounded off ridge or flat... 36

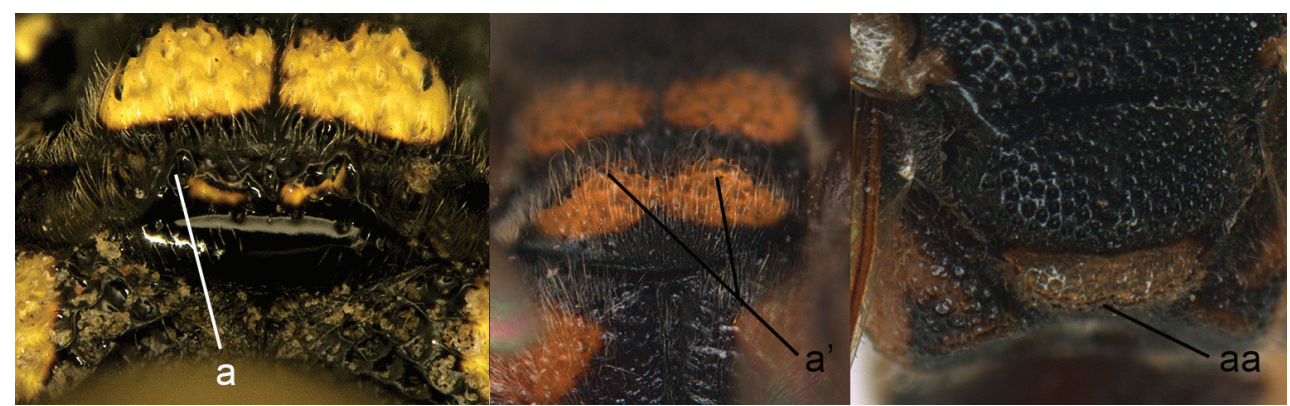

Figure 34. Metanotum. a. Antepipona asiamontana Gusenleitner; a' Apodynerus f. formosensis (von Schulthess) aa Euodynerus trilobus (Fabricius).

35 Clypeus higher than wide (35a); metanotum with truncate teeth; mid-anterior face of pronotum smooth and with short transverse rugae (35b); tergum I distinctly narrower than tergum II (35c); male terminal antennal segment small $(35 \mathrm{~d})$ Apodynerus Giordani Soika - $\quad$ Clypeus wider than high (35aa); mid-anterior face of pronotum usually densely punctate and with an upper trace of transverse carina (35bb); tergum I slightly narrower than tergum II $(35 \mathrm{cc})$; male terminal antennal segment relatively large (35dd)

Antepipona de Saussure

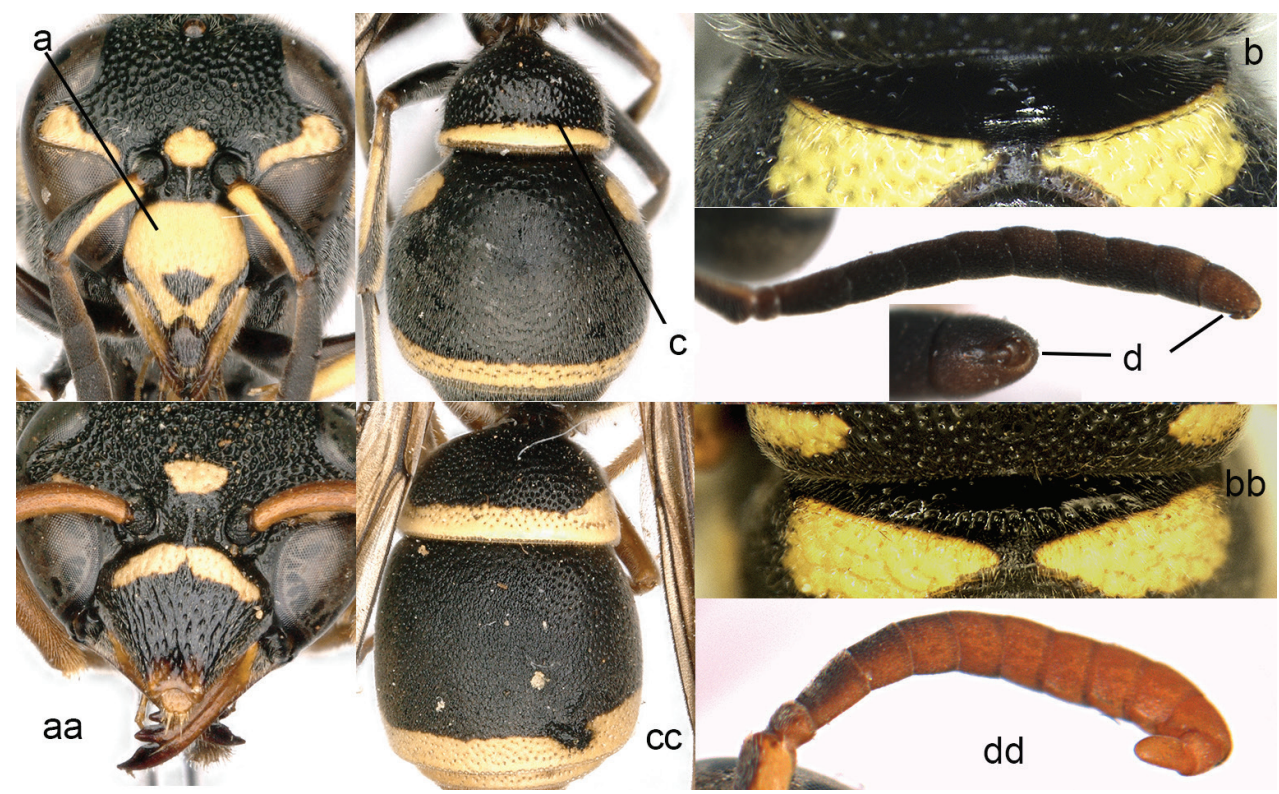

Figure 35. Head in frontal view (a, aa), metasoma in dorsal view $(\mathbf{c}, \mathbf{c c})$, anterior face of pronotum (b, bb) and antenna (d, dd). a-d Apodynerus troglodytes (de Saussure) aa, cc Antepipona silaos (de Saussure) bb Antepipona menkei Giordani Soika; dd. Antepipona rufescens (Smith). 
Tergum II without lamella behind transverse band, at most with narrow border (36aa). Note: few Euodynerus spp. may possess a distinct lamella on tergum II (see 45a), they can be separated from Leptochilus by having tergum I not depressed subapically (depressed in Leptochilus); and differs from Gribodia, Stenodynerellus and Epsilon by having oval axillary fossa, broader than long (slit-like, narrower than long in Gribodia, Stenodynerellus and Epsilon)..... 40

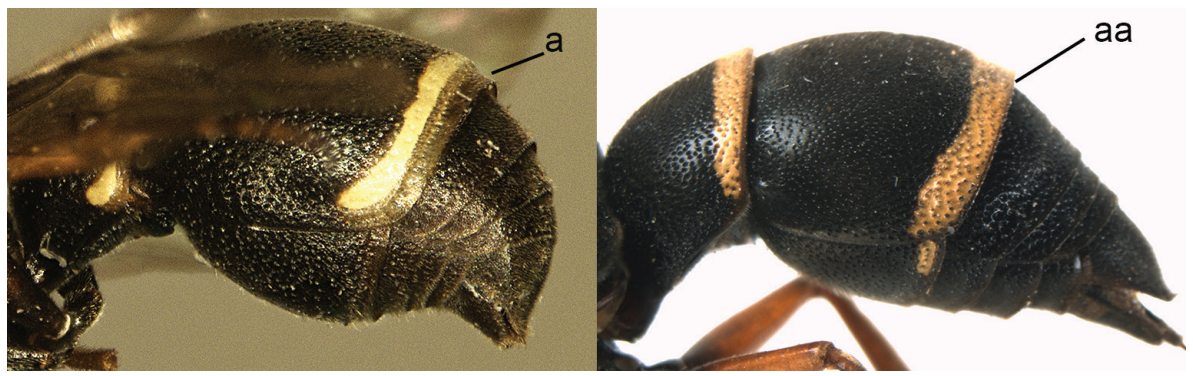

Figure 36. Metasoma in lateral view. a Leptochilus m. medane (Gribodo) aa Anterhynchium flavomarginatum micado (Kirsch).

Tergum I depressed subapically, gradually widened with lateral sides divergent in dorsal view (37 aa); propodeum with submarginal carina projecting as rounded lobe above valvula, bilamellate (37bb); epicnemial carina absent (37cc); axillary fossa oval, broader than long (37dd)...Leptochilus de Saussure - $\quad$ Tergum I not depressed subapically, usually with lateral sides roughly parallel in dorsal view (37aa); propodeum with submarginal carina not differentiated from valvula, mono-lamellate (37bb; except Epsilon); epicnemial carina present $(37 \mathrm{cc})$; axillary fossa narrower than long, slit-like (37dd)....

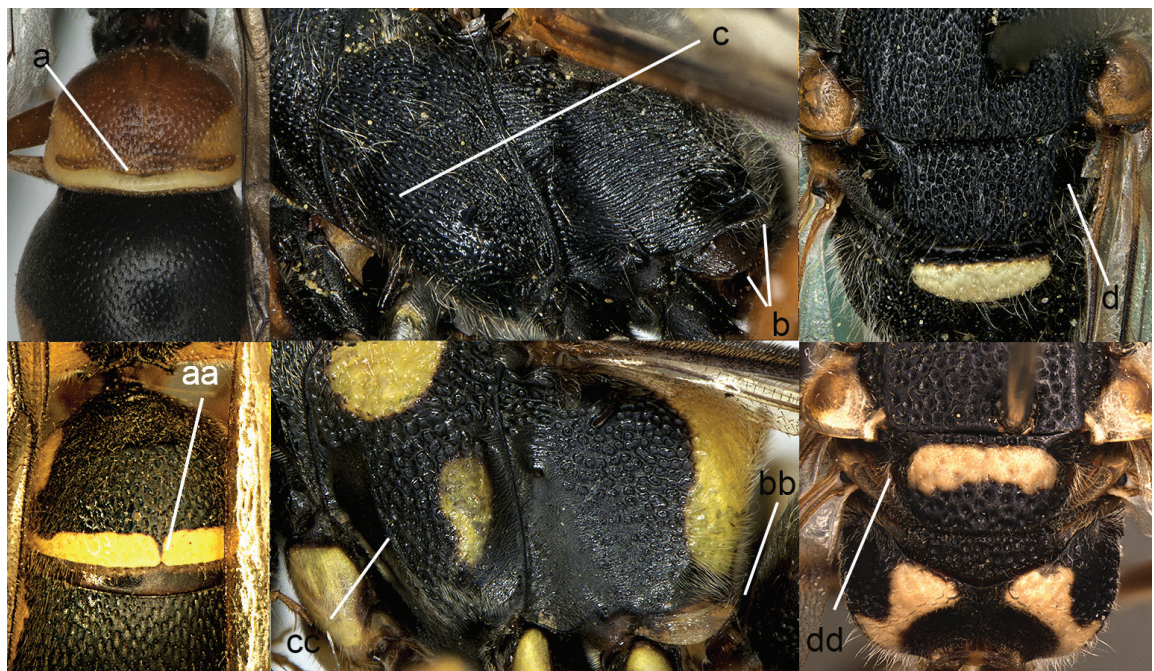

Figure 37. Metasomal tergum I (a, aa) in dorsal view, propodeum in lateral view (b, bb), mesosoma in lateral view (c, cc) and metanotum in dorsal view (d, dd). a-d Leptochilus m. mauritanicus (Lepeletier) aa Gribodia confluenta (Smith) bb, cc Stenodyneriellus guttulatus (de Saussure) dd Stenodyneriellus sp. 
38 Palpal formula 5:3 (38a); male vertex sometimes with large and deep depression (38b); propodeum without shelf-like protruding part and with lateral carinae well developed (38c); [metanotum angulated, second submarginal cell with second recurrent vein nearly or completely interstitial with third submarginal cell; terga I-V each with apical lamella] ...... Gribodia Zavattari - $\quad$ Palpal formula 6:4 (38aa); male vertex without large and deep depression (38bb); propodeum with shelf-like protruding part (38cc) or absent (38cc')

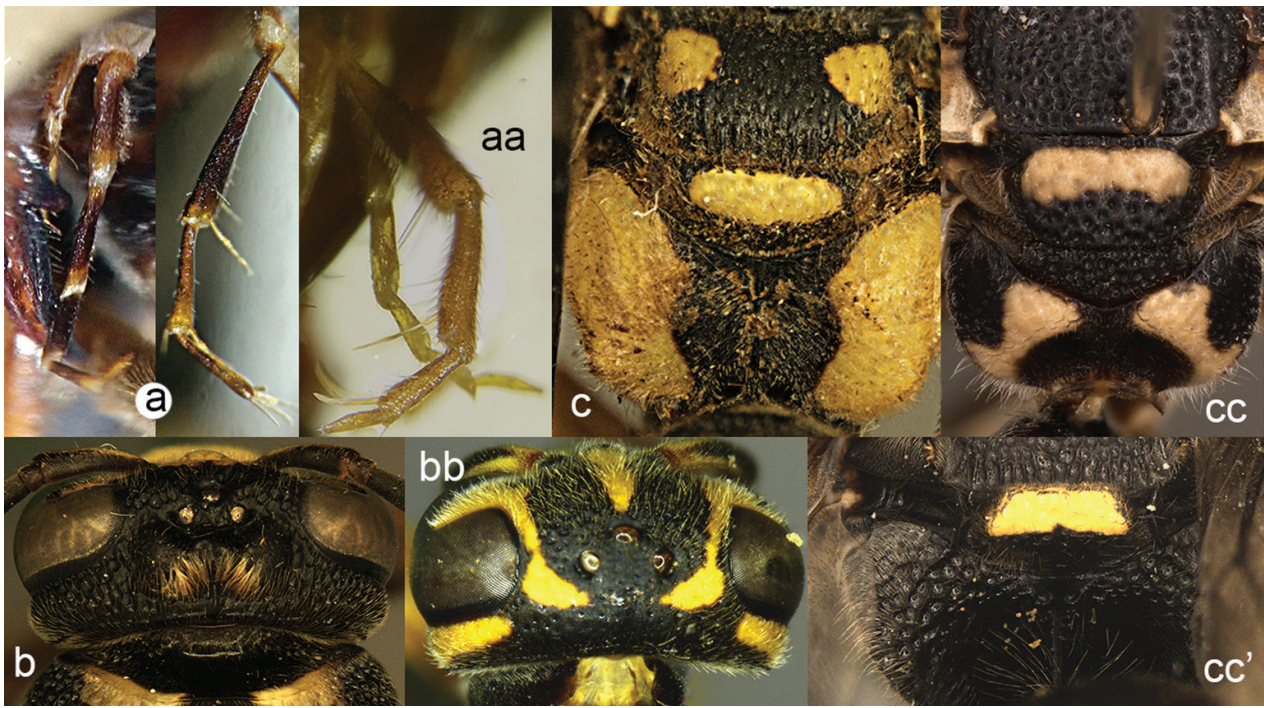

Figure 38. Maxillary palpus (a left) and labial palpus (b right), mouthpart palpi (aa), head in dorsal view (b, bb), part of mesosoma in dorso-caudal view (c, cc, cc'). a-c Gribodia sp. aa, bb Stenodyneriellus guttulatus (de Saussure) cc Stenodyneriellus sp. cc' Epsilon dyscherum (de Saussure).

39 Clypeus longer than wide, apical margin usually truncate (39a); propodeum with submarginal carina not differentiated from valvula (39b); propodeum usually with dorsal surface at about same level as metanotum, lateral margin rounded; metanotum usually smoothly convex (39c); terga I-V each with apical lamella (39d); second submarginal cell with second recurrent vein variable.....

Stenodyneriellus Giordani Soika Clypeus longer than wide, apical margin emarginate (39aa); propodeum with submarginal carina projecting as rounded lobe above valvula (39bb); propodeum without raised shelf-like part, lateral margin carinate; metanotum angulated (39cc); only tergum II with lamella (39dd); second submarginal cell with second recurrent vein nearly or completely interstitial with third submarginal cell (39ee) Epsilon de Saussure 


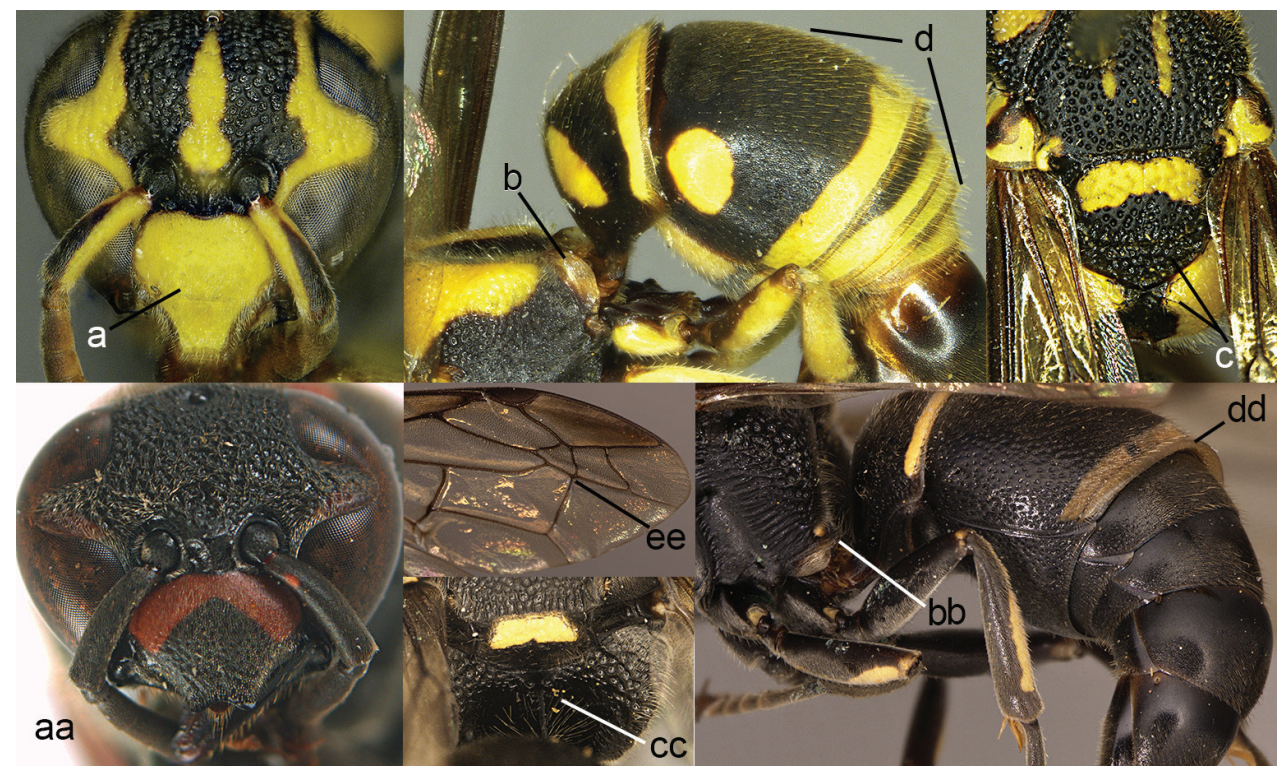

Figure 39. Head in frontal view (a, aa), part of meso- and metasoma (b, d, bb, dd), part of mesosoma in dorsal view (c, cc) and distal part of forewing (ee). a-d Stenodyneriellus guttulatus (de Saussure) aa-ee Epsilon dyscherum (de Saussure).

40 Axillary fossa in dorsal view much narrower than long, often slit-like (40a); tegula short, not exceeding parategula......................................................41

- $\quad$ Axillary fossa in dorsal view not slit-like, at least as wide as long, oval (40aa); tegula usually equal to or exceeding parategula.....

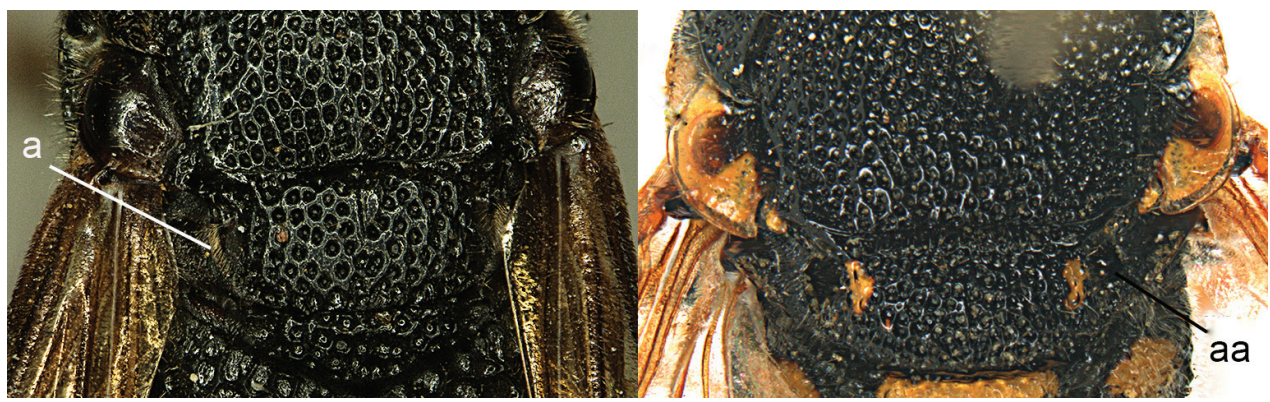

Figure 40. Part of mesosoma in dorsal view. a Orientalicesa unifasciata (von Schulthess) aa Euodynerus p. posticus (Herrich-Schäffer). 
41 Propodeum with raised shelf-like part nearly at level of metanotum, metanotum flat (41a) ................................................................................ 42

- $\quad$ Propodeum below level of metanotum, metanotum various (41aa) ............. 43

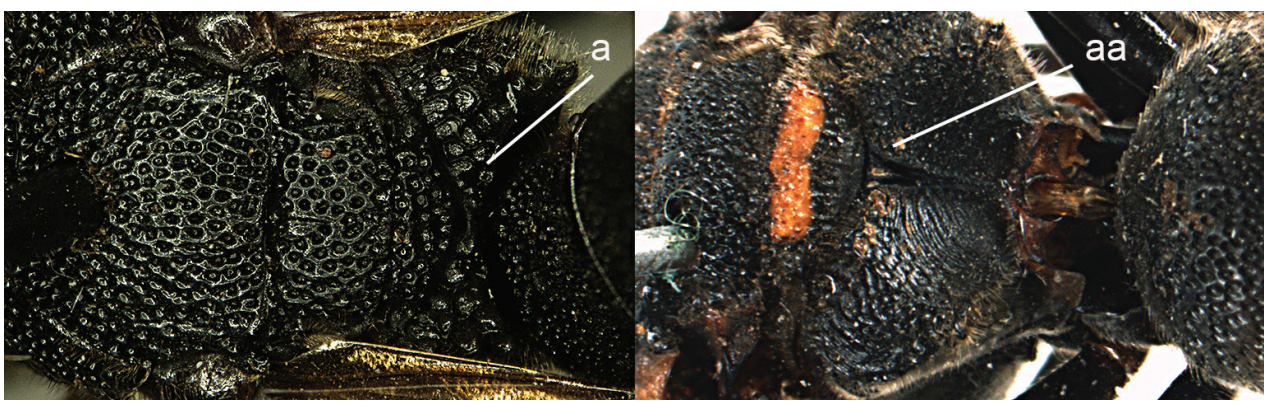

Figure 4I. Part of mesosoma in dorsal view (a) and in dorso-caudal view (aa). a Orientalicesa unifasciata (von Schulthess) aa Anterhynchium (Dirhynchium) flavopunctatum (Smith).

42 Forewing with third submarginal cell separated from apex of marginal cell by about half its length (42a); male sternum VII with basal truncate process (42b) Allorhynchium van der Vecht - $\quad$ Forewing with third submarginal cell separated from apex of marginal cell by about its own length (42aa); male sternum VII without process (42bb)

Orientalicesa Koçak and Kemal

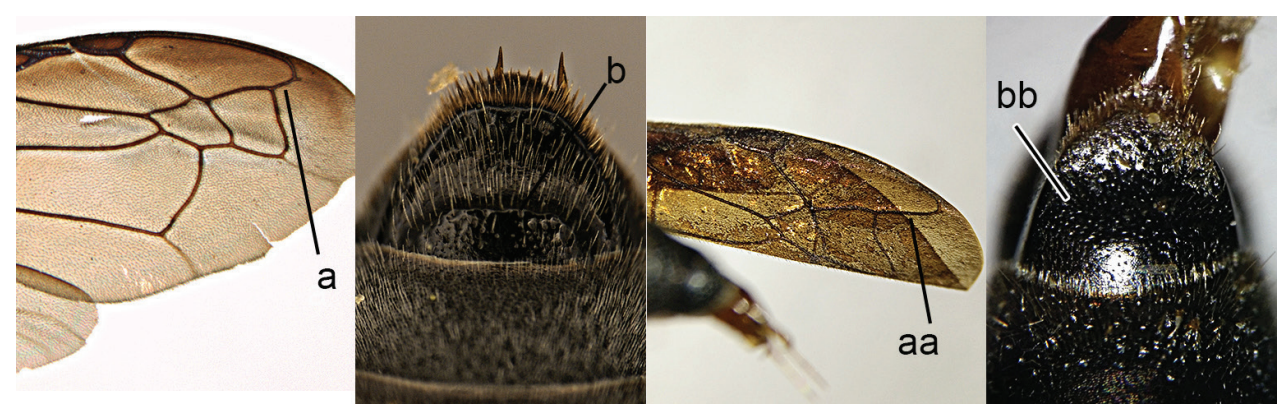

Figure 42. Distal part of forewing (a, aa) and terminal sternum of male (sternum VII) (b, bb). a, b Allorhynchium argentatum (Fabricius) aa, bb Orientalicesa unifasciata (von Schulthess). 
43 Parastigma of forewing more than half length of pterostigma, measured along posterior part or nearly equal (43a); palpal formula 6:4 (38aa).... 44

- Parastigma shorter than half length of pterostigma, measured along posterior part (43aa); palpal formula 5:3 (38a) Okinawepipona Yamane
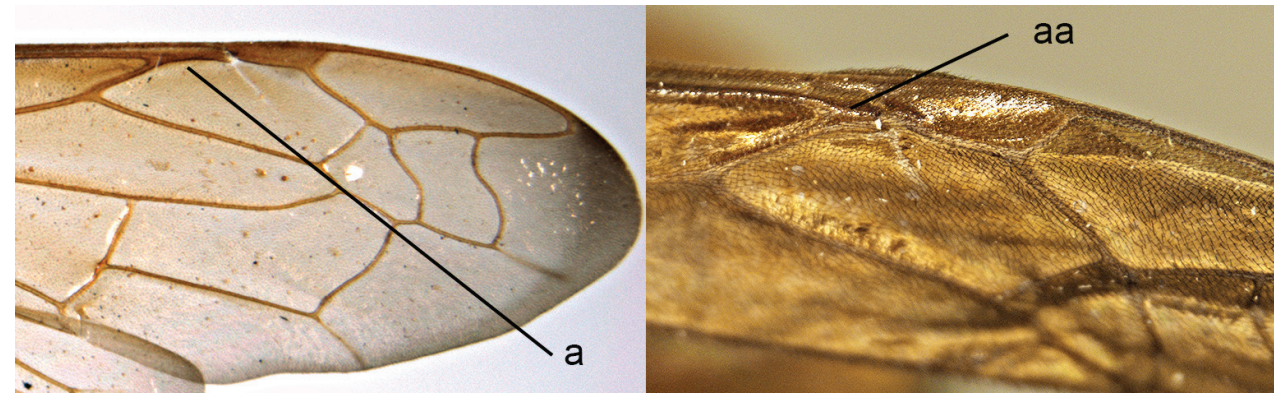

Figure 43. Part of forewing. a Rhynchium carnaticum (Fabricius) b Okinawepipona kojimai (Giordani Soika).

44 Mesoscutum posteriorly and scutellum smooth, very sparsely and finely punctate (44a); metanotum depressed medially (44b); male middle femur basally emarginated (44c).

Rhynchium Spinola

- $\quad$ Mesoscutum and scutellum richly punctate throughout (44aa); metanotum not depressed medially (44bb); male middle femur not basally emarginate $(44 \mathrm{cc})$

Anterhynchium de Saussure

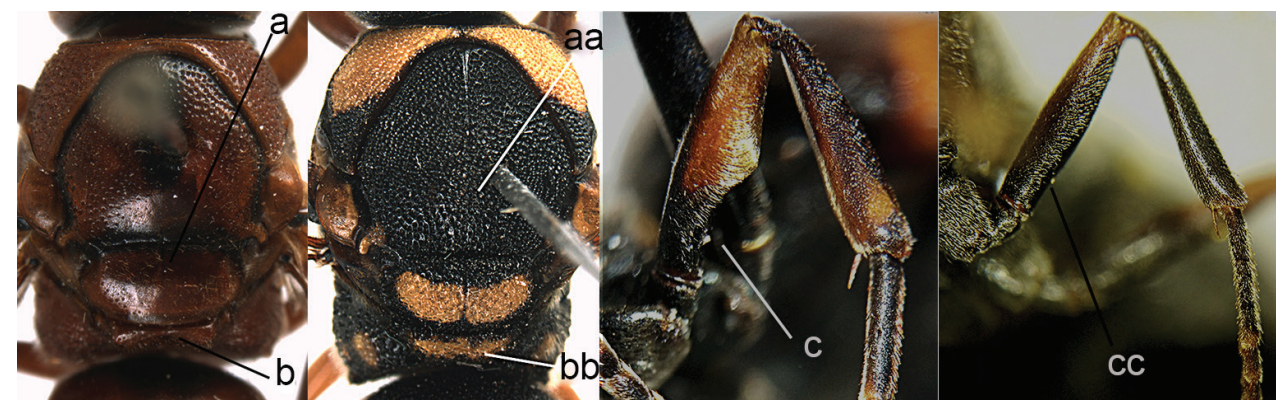

Figure 44. Mesosoma in dorsal view (a, b, aa, bb) and middle leg of male (c, cc). a, b Rhynchium carnaticum (Fabricius) c Rhynchium q. quinquecinctum (Fabricius) aa, bb Anterhynchium flavomarginatum micado (Kirsch) cc Anterhynchium sp. 
45 Tergum I behind apical band with well-developed lamella (45a)

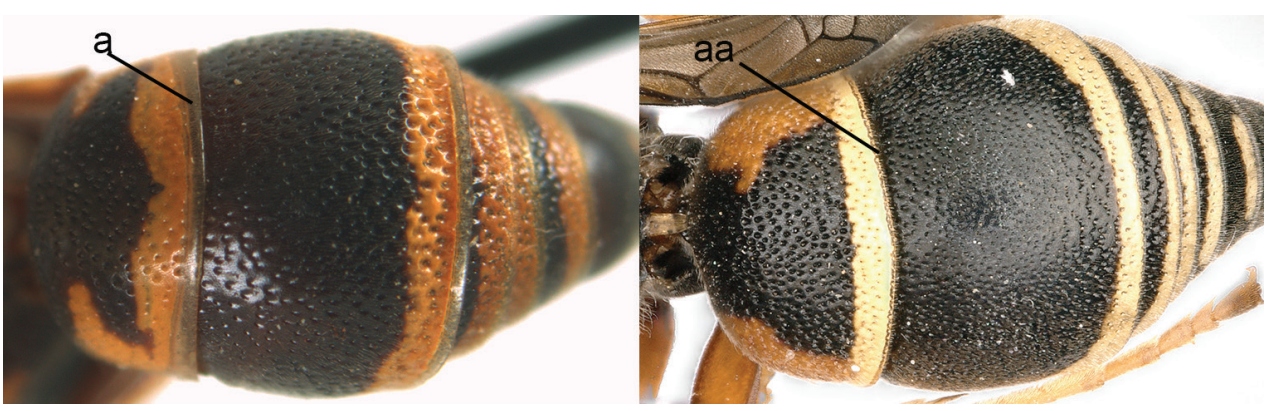

Figure 45. Metasoma in dorsal view. a Euodynerus trilobus (Fabricius) aa Pseudepipona h. herrichii (de Saussure).

46 Metanotum between horizontal and vertical area with hemi-circular carina (46a) Antodynerus de Saussure

- Metanotum between areas without hemi-circular shaped carina (46aa) Euodynerus Dalla Torre

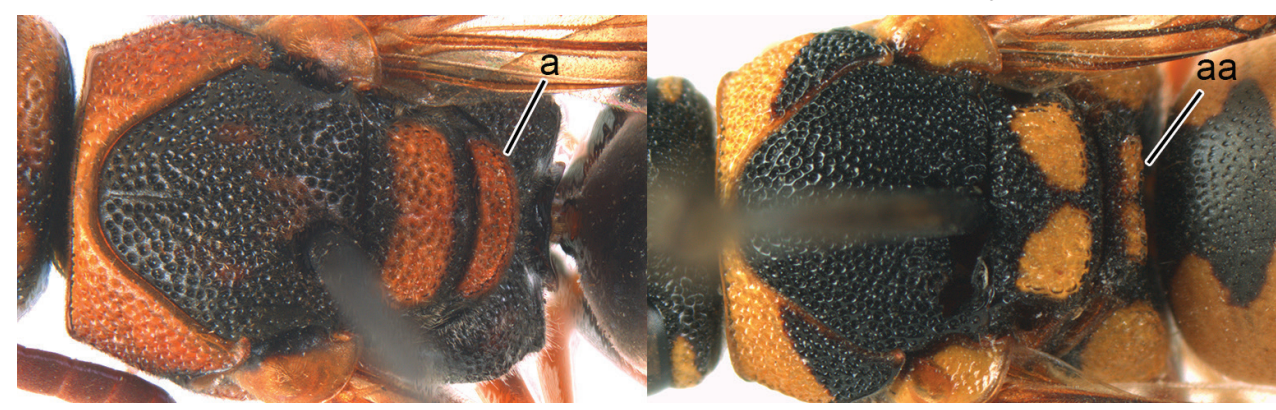

Figure 46. Mesosoma in dorsal view. a Antodynerus limbatus (de Saussure) aa Euodynerus d. dantici (Rossi).

47 Pretegular carina absent (47a) 48

- $\quad$ Pretegular carina present, at least posteriorly (47aa)

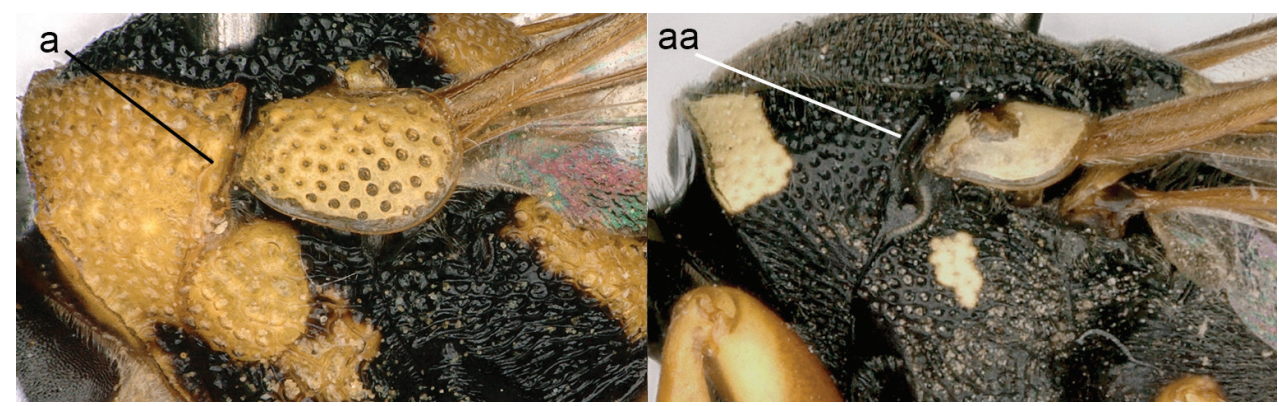

Figure 47. Part of mesosoma in lateral view. a Brachyodynerus m. magnificus (Morawitz) aa Pseudepipona h. herrichii (de Saussure). 
Tegula sparsely punctate, slightly exceeding parategula and much smaller than scutellum (48a); mid-anterior face of pronotum smooth (48b); metanotum with lateral lamellae (48c); female with single cephalic fovea situated near occipital carina (48d)

Parodontodynerus Blüthgen

- $\quad$ Tegula densely punctate, distinctly exceeding parategula, almost as large as scutellum (48aa); mid-anterior face of pronotum densely punctate (48bb); metanotum without lateral lamellae (48cc); female with single cephalic fovea situated halfway posterior ocelli and occipital carina (48dd) Brachyodynerus Blüthgen

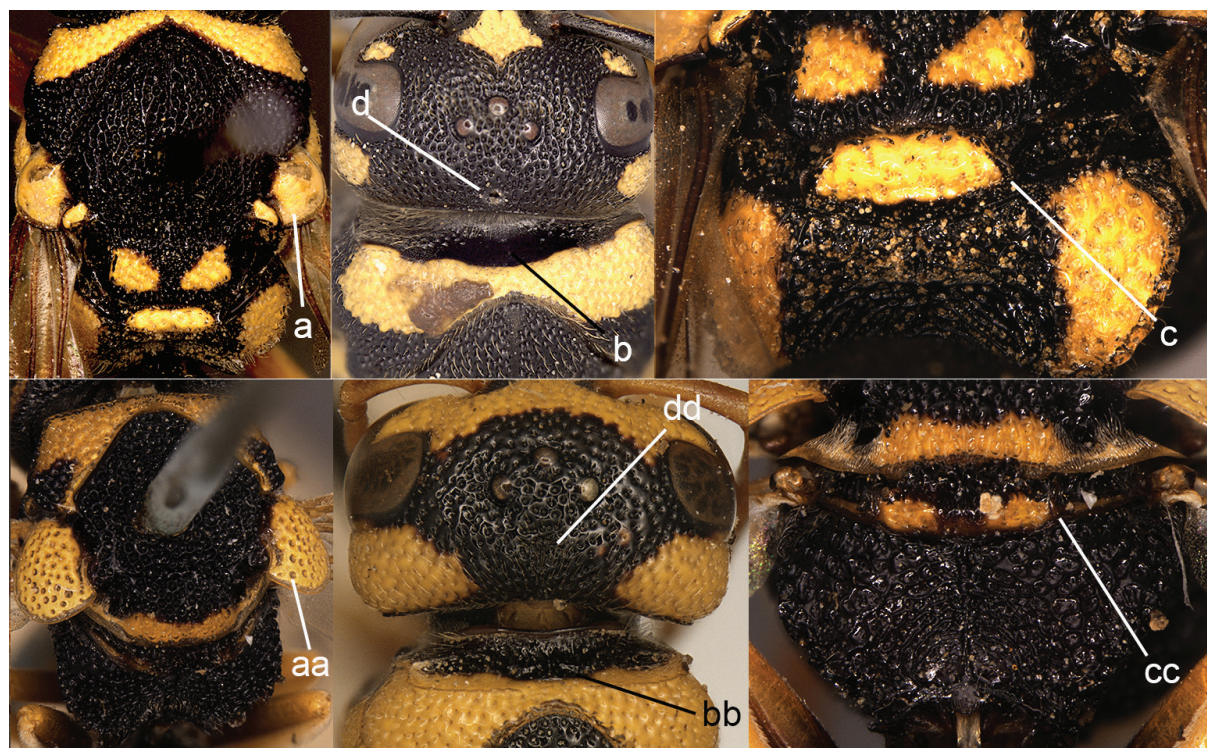

Figure 48. Mesosoma in dorsal view (a, aa), head and pronotum in dorsal view ( $\mathbf{b}, \mathbf{d}, \mathbf{b} \mathbf{b}, \mathbf{d d})$ and metanotum in dorsal view (c, cc). a-d Parodontodynerus e. ephippium (Klug) aa-dd Brachyodynerus magnificus (Morawitz).

49 Tegula narrower and longer, surpassing parategula posteriorly (49a). [female vertex with reniform fovea, about as wide as ocellar triangle; hind coxa with ventral lobes] Allodynerus Blüthgen

- $\quad$ Tegula broad, equal to parategula posteriorly (49aa) 50
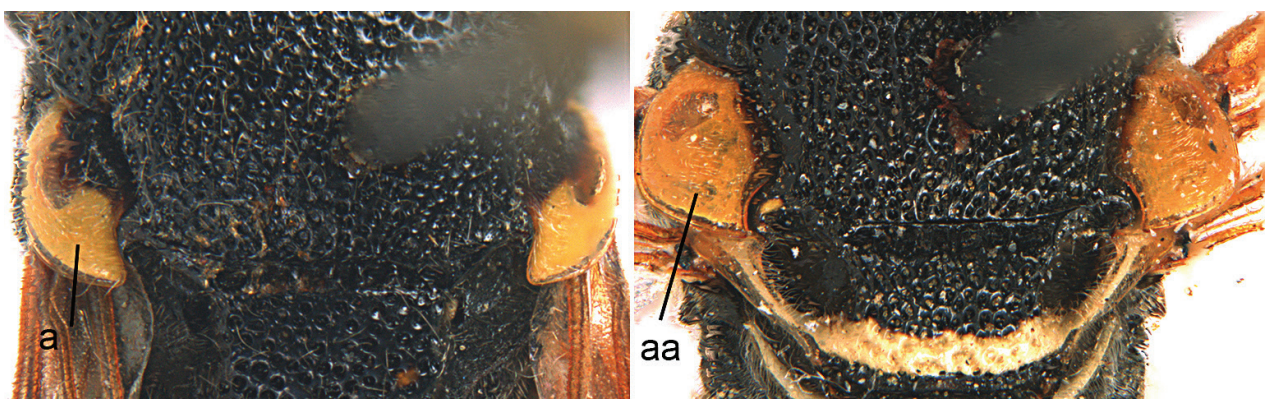

Figure 49. Part of mesonotum showing tegula and parategula. a Allodynerus mandschuricus Blüthgen aa Pseudepipona herrichii siberia Kurzenko. 
50 Propodeal valvula mono-lamellate (50a), with transverse carina, and with a dentate ridge laterally (50b); [metanotum ridge roughly bidentate-shaped]...

Pseudepipona de Saussure

- $\quad$ Propodeal valvula bilamellate (50aa), without transverse carina, and without dentate ridge laterally; [small species ( $6 \mathrm{~mm}$ body length); anterior face of pronotum smooth; vertex with very small pits] ........ Asiodynerus Kurzenko
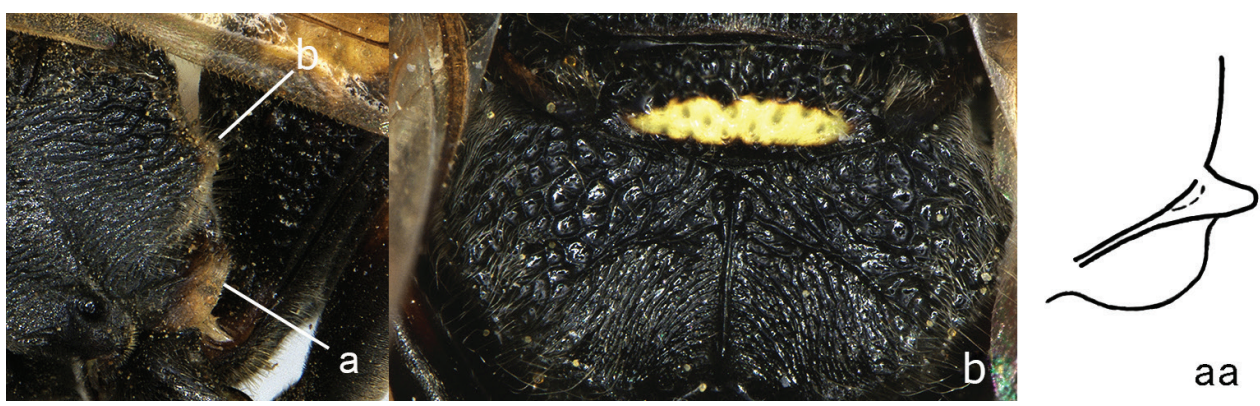

Figure 50. Propodeum in lateral view (a, aa) and in caudal view (b). a, b Pseudepipona herrichii siberia Kurzenko aa Asiodynerus lucifer (Kostylev), after Kurzenko (1977).

\section{Checklist of the species of the subfamily Eumeninae from China}

\section{Allodynerus Blüthgen, 1938}

Allodynerus Blüthgen, 1938 (1937), Konowia 16: 280; Type species: "Lionotus floricola

Sauss. 1852" [= Odynerus floricola de Saussure, 1853].

Allodynerus delphinalis delphinalis (Giraud, 1866)

Allodynerus mandschuricus Blüthgen, 1953

\section{Allorbynchium van der Vecht, 1963}

Allorhynchium van der Vecht, 1963, Zool. Verh., Leiden 60: 57 (key), 58, genus. Type

species: Vespa argentata Fabricius, 1804.

Allorhynchium chinense (de Saussure, 1862)

Allorhynchium lugubrinum (Cameron, 1900)

Allorhynchium metallicum (de Saussure, 1852)

\section{Ancistrocerus Wesmael, 1836}

Ancistrocerus Wesmael, 1836, Bull. Acad. R. Belg. 3: 45. Type species: Vespa parietum

Linnaeus, 1758.

Ancistrocerus arcanus Giordani Soika, 1993

Ancistrocerus aureovillosus Giordani Soika, 1977

Ancistrocerus deqinensis You and Li, 2013

Ancistrocerus frigidus Giordani Soika, 1977 (1976)

Ancistrocerus hirsutus hirsutus (Meade-Waldo, 1910)

Ancistrocerus hirsutus supiensis Giordani Soika, 1977 (1976)

Ancistrocerus hirsutus tinkiensis Giordani Soika, 1977 (1976) 
Ancistrocerus khangmarensis Giordani Soika, 1966

Ancistrocerus krausei Giordani Soika, 1966

Ancistrocerus melanocerus (Dalla Torre, 1894)

Ancistrocerus melanurus Morawitz, 1889

Ancistrocerus montuosus Gusenleitner, 1993

Ancistrocerus nigricornis (Curtis, 1791)

Ancistrocerus parapoloi Giordani Soika, 1966

Ancistrocerus parietum (Linnaeus, 1758)

Ancistrocerus rufofrustius Tan \& Carpenter, nom. n.

Replacement name for Ancistrocerus rufopictus (Kostylev, 1940) (junior primary

homonym of Odynerus lineaticollis var. rufopictus Meade-Waldo, 1915).

Ancistrocerus sikhimensis (Bingham, 1897)

Ancistrocerus terayamai Yamane, 1993

Ancistrocerus tibetanus Giordani Soika, 1966

Ancistrocerus transpunctatus You \& Li, 2013

Ancistrocerus trifasciatus shibuyai (Yasumatsu, 1938)

Ancistrocerus waltoni (Meade-Waldo, 1910)

\section{Antepipona de Saussure, 1855}

Antepipona de Saussure, 1855, Ét. Fam. Vesp. 3: 244. Type species: Odynerus silaos de

Saussure, 1853.

Antepipona asiamontana Gusenleitner, 2004

Antepipona biguttata (Fabricius, 1787)

Antepipona bipustulata (de Saussure, 1855)

Antepipona brunneola Giordani Soika, 1986

Antepipona deflenda (Saunders, 1853)

Antepipona excelsa excelsa Giordani Soika, 1982

Antepipona ferruginea Kim \& Yamane, 2003

Antepipona ferruginea Kim \& Yamane, 2003

Antepipona guttata diffinis (de Saussure, 1855)

Antepipona menkei Giordani Soika, 1986

Antepipona ovalis (de Saussure, 1853)

Antepipona plurimacula Giordani Soika, 1971

Antepipona rufescens (Smith, 1857)

Antepipona shantungensis Giordani Soika, 1993

Antepipona sexfasciata Soika, 1986

Antepipona tytides (Cameron, 1904)

\section{Anterhynchium de Saussure, 1863}

Anterhynchium de Saussure, 1863, Mém. Soc. Phys. Hist. Nat. Genève 17: 205. Type species: Rygchium [= Rhynchium] synagroides de Saussure, 1852.

Anterhynchium (Anterhynchium) mellyi (de Saussure, 1852)

Anterhynchium (Dirhynchium) flavomarginatum flavomarginatum (Smith, 1852) 
Anterhynchium (Dirhynchium) flavomarginatum formosicola (von Schulthess, 1934)

Anterhynchium (Dirhynchium) flavopunctatum flavopunctatum (Smith, 1852)

Anterhynchium (Dirhynchium) flavopunctatum opulentum (Giordani Soika, 1973)

Anterhynchium (Dirhynchium) inamurai (Sonan, 1937)

Anterhynchium (Dirhynchium) yunnanensis Giordani Soika, 1973

\section{Antodynerus de Saussure, 1855}

Antodynerus de Saussure, 1855, Ét. Fam. Vesp. 3: 287.Type species: “Odynerus punctum

(Fabricius)" sensu de Saussure, 1853 [= Vespa flavescens Fabricius, 1775]

Antodynerus limbatus (de Saussure, 1852)

\section{Apodynerus Giordani Soika, 1993}

Apodynerus Giordani Soika, 1993, Boll. Mus. Civ. Stor. Nat. Venezia 42: 155. Type species: Odynerus troglodytes de Saussure, 1855.

Apodynerus formosensis continentalis Giordani Soika, 1994

Apodynerus formosensis formosensis (von Schulthess, 1934)

Apodynerus troglodytes troglodytes (de Saussure, 1855)

Apodynerus yayeyamensis yayeyamensis (Matsmura, 1926)

\section{Archancistrocerus Giordani Soika, 1986}

Archancistrocerus Giordani Soika, 1986, Boll. Mus. Civ. Stor. Nat. Venezia 35: 143,

genus. Type species: Archancistrocerus diffinis Giordani Soika, 1986, monotypy.

Archancistrocerus diffinis Giordani Soika, 1986

Note: Archancistrocerus is a junior synonym and will be included in Allorhynchium

(Tan et al. 2018b, submitted).

\section{Asiodynerus Kurzenko, 1977}

Asiodynerus Kurzenko, 1977, Ins. Mongol. 5: 557. Type species: Odynerus lucifer Kostylev, 1937.

Asiodynerus lucifer (Kostylev, 1937 (1936))

\section{Brachyodynerus Blüthgen, 1938}

Brachyodynerus Blüthgen, 1938, Deutsch. Entomol. Zeitschr.: 450, 459, genus. Type species: Odynerus (Lionotus) magnificus Morawitz, 1867.

Brachyodynerus perarrus Kurzenko, 1977

\section{Calligaster de Saussure, 1852}

Calligaster de Saussure, 1852, Ét. fam. Vesp. 1: 22, genus. Type species: Calligaster cyanoptera de Saussure, 1852.

Calligaster himalayensis (Cameron, 1904)

\section{Coeleumenes van der Vecht, 1963}

Coeleumenes van der Vecht, 1963, Zool. Verh., Leiden 60: 45, genus. Type species: Montezumia impavida Bingham, 1897 
Coeleumenes burmanicus (Bingham, 1897)

Coeleumenes thoracicus (Sonan, 1939)

\section{Cyrtolabulus van der Vecht, 1969}

Cyrtolabulus van der Vecht, 1969, Entomol. Ber., Amst. 29: 1, replacement name for

Cyrtolabus van der Vecht, 1963, non Voss, 1925. Type species: Cyrtolabus suavis van der Vecht, 1963.

Cyrtolabulus exiguus (de Saussure, 1853)

Cyrtolabulus yunnanensis Lee, 1982

\section{Delta de Saussure, 1855}

Delta de Saussure, 1855, Ét. Fam. Vesp. 3: 130, 132, 143. Type species: Vespa maxillosa DeGeer, 1775 [= Vespa emarginata Linnaeus, 1758]

Delta campaniforme campaniforme (Fabricius, 1775)

Delta conoideum (Gmelin, 1790)

Delta esuriens okinawae Giordani Soika, 1986

Delta pyriforme pyriforme (Fabricius, 1775)

\section{Discoelius Latreille, 1809}

Discoelius Latreille, 1809, Gen. Crust. et Insect. 4: 140. Type species: Vespa zonalis Panzer, 1801, monotypy.

Discoelius dufourii dufourii (Lepeletier, 1841)

Discoelius dufourii manchurianus Yasumatsu, 1934

Discoelius emeishanensus Zhou and Li, 2013

Discoelius esakii Yasumatsu, 1934

Discoelius longinodus Yamane, 1996

Discoelius nigriclypeus Zhou \& Li, 2013

Discoelius wangi Yamane, 1996

Discoelius zonalis (Panzer, 1801)

\section{Ectopioglossa Perkins, 1912}

Ectopioglossa Perkins, 1912, Ann. Mag. Nat. Hist. (8) 9: 118, genus. Type species: Ectopioglossa australensis Perkins, 1912, monotypy.

Ectopioglossa ovalis Giordani Soika, 1993

Ectopioglossa taiwana (Sonan, 1938)

\section{Epsilon Saussure, 1855}

Epsilon de Saussure, 1855, Ét. Fam. Vesp. 3: 229, 252. Type species: Odynerus dyscherus de Saussure, 1852.

Epsilon fujianense Lee, 1981

\section{Eumenes Latreille, 1802}

Eumenes Latreille, 1802, Hist. Nat. Crust. Ins. 3: 360, genus. Type species: "Eumenes coarctata, Fab." [= Vespa coarctata Linnaeus, 1758]. 
Eumenes architectus Smith, 1859

Eumenes assamensis Meade-Waldo, 1910

Eumenes atrophicus (Fabricius, 1798)

Eumenes buddha Cameron, 1897

Eumenes coarctatus coarctatus (Linnaeus, 1758)

Eumenes coronatus coronatus (Panzer, 1799)

Eumenes ferrugiantennus Zhou, Chen \& Li, 2012

Eumenes formosensis Giordani Soika, 1973

Eumenes fraterculus Dalla Torre, 1894

Eumenes fulvopilosellus Giordani Soika, 1965

Eumenes kangrae Dover, 1925

Eumenes kiangsuensis Giordani Soika, 1941

Eumenes labiatus flavoniger Giordani Soika, 1941

Eumenes labiatus labiatus Giordani Soika, 1941

Eumenes labiatus sinicus Giordani Soika, 1941

Eumenes mediterraneus manchurianus Giordani Soika, 1971

Eumenes micado Cameron, 1904 (Kim and Yoon (2001) state that the record is very doubtful)

Eumenes multipictus de Saussure, 1855

Eumenes nigriscutatus Zhou, Chen \& Li, 2012

Eumenes pedunculatus pedunculatus (Panzer, 1799)

Eumenes pomiformis (Fabricius, 1781)

Eumenes punctatus de Saussure, 1852

Eumenes quadratus obsoletus Dover, 1926

Eumenes quadratus quadratus Smith, 1852

Eumenes quadratus urainus Sonan, 1939

Eumenes rubronotatus Pérez, 1905

Eumenes septentrionalis khangmarensis Giordani Soika, 1966

Eumenes septentrionalis septentrionalis Giordani Soika, 1940

Eumenes tosawae lofouensis Giordani Soika, 1973

Eumenes tosawae tosawae Giordani Soika, 1934

Eumenes transbaicalicus Kurzenko, 1984

Eumenes tripunctatus (Christ, 1791)

Eumenes variepunctatus Giordani Soika, 1941

\section{Euodynerus Dalla Torre, 1904}

Euodynerus Dalla Torre, 1904, Gen. Ins. 19: 38. Type species: Vespa dantici Rossi, 1790.

Euodynerus (Euodynerus) caspicus caspicus (Morawitz, 1873)

Euodynerus (Euodynerus) dantici brachytomus (Kostylev, 1940)

Euodynerus (Euodynerus) dantici violaceipennis Giordani Soika, 1973

Euodynerus (Euodynerus) fastidiosus (de Saussure, 1853)

Euodynerus (Euodynerus) rufinus rufinus Blüthgen, 1942 
Euodynerus (Euodynerus) semisaecularis semisaecularis (Dalla Torre, 1889)

Euodynerus (Euodynerus) variegatus kruegeri (von Schulthess, 1928)

Euodynerus (Pareuodynerus) adiacens Giordani Soika, 1973

Euodynerus (Pareuodynerus) deqinensis $\mathrm{Ma}$, Chen \& Li, 2017

Euodynerus (Pareuodynerus) ferrugineus Ma, Chen \& Li, 2017

Euodynerus (Pareuodynerus) nipanicus nipanicus (von Schulthess, 1908)

Euodynerus (Pareuodynerus) nipanicus ryukyuensis Tano, 1987

Euodynerus (Pareuodynerus) nipanicus tonkinensis Giordani Soika, 1973

Euodynerus (Pareuodynerus) notatus notatus (Jurine, 1807)

Euodynerus (Pareuodynerus) quadrifasciatus quadrifasciatus (Fabricius, 1793)

Euodynerus (Pareuodynerus) similinipanicus Ma, Chen \& Li, 2017

Euodynerus (Pareuodynerus) strigatus (Radoszkowski, 1893)

Euodynerus (Pareuodynerus) trilobus (Fabricius, 1787)

\section{Gribodia Zavattari, 1912}

Gribodia Zavattari, 1912, Arch. Naturgesch. 78A (4): 161. Type species: Monobia cavifrons Gribodo, 1891 [= Odynerus confluenta Smith, 1857], monotypy. Gribodia nigra Nguyen \& Xu, 2015

\section{Jucancistrocerus Blüthgen, 1938}

Jucancistrocerus Blüthgen, 1938, Deutsch. Entomol. Zeitschr.: 442, 460.Type species:

Odynerus (Ancistrocerus) jucundus Mocsáry, 1883, monotypy.

Jucancistrocerus (Jucancistrocerus) alashanicus Kurzenko, 1977

Jucancistrocerus (Jucancistrocerus) angustifrons (Kostylev, 1940)

Jucancistrocerus (Eremodynerus) atrofasciatus (Morawitz, 1885)

Jucancistrocerus (Eremodynerus) chotanensis (Blüthgen, 1942)

\section{Katamenes Meade-Waldo, 1910}

Katamenes Meade-Waldo, 1910, Ann. Mag. Nat. Hist. (8) 5: 46, genus. Type species: Katamenes watsoni Meade-Waldo, 1910, monotypy.

Katamene arbustorum arbustorum (Panzer, 1799)

Katamene indetonsus (Morawitz, 1895)

Katamene tauricus tauricus (de Saussure, 1855)

\section{Labus de Saussure, 1867}

Labus de Saussure, 1867, Reise Novara, Zool. 2 (1), Hym.: 3, genus. Type species: Labus spiniger de Saussure, 1867

Labus exiguus (de Saussure, 1855)

Labus lofuensis Giordani Soika, 1973

\section{Leptochilus de Saussure, 1853}

Leptochilus de Saussure, 1853, Ét. Fam. Vesp 1: 233. Type species: Pterocheilus mauritianus [!] [= Pterocheilus mauritanicus Lepeletier, 1841]. 
Leptochilus (Lionotulus) chinensis Gusenleitner, 2001

Leptochilus (Lionotulus) gobicus (Kostylev, 1940)

Leptochilus (Lionotulus) incertus (Kostylev, 1940)

Leptochilus (Neoleptochilus) tibetanus Giordani Soika, 1966

\section{Lissodynerus Giordani Soika, 1993}

Lissodynerus Giordani Soika, 1993, Boll. Mus. Civ. Stor. Nat. Venezia 42: 135. Type species: Odynerus septemfasciatus Smith, 1857.

Lissodynerus septemfasciatus feanus (Giordani Soika, 1941)

\section{Leptomicrodynerus Giordani Soika, 1985}

Leptomicrodynerus Giordani Soika, 1985, Lavori Soc. Ven. Sci. Nat. 10: 37. Type species: Leptomicrodynerus tieshengi Soika, 1985, monotypy.

Leptomicrodynerus tieshengi Giordani Soika, 1985

Note: The characteristics of this genus also fit well with Eumenidiopsis Giordani

Soika, 1939, and further research is needed to solve the problem.

\section{Nortozumia van der Vecht, 1937 (new record)}

Nortozumia van der Vecht, 1937, Treubia 16: 263, genus. Type species: Zethus rufofemoratus Cameron, 1903.

Nortozumia sp.

\section{Odynerus Latreille, 1802}

Odynerus Latreille, 1802, Hist. Nat. Crust. Ins. 3: 362. Type species: Vespa spinipes Linnaeus, 1758.

Odynerus (Odynerus) tristis tianshanicus Kurzenko, 1977.

\section{Okinawepipona Yamane, 1987}

Okinawepipona Yamane, 1987, Mem. Kagoshima Univ. Res. Center S. Pacific 8: 52.

Type species: Anterhynchium kogimai Giordani Soika, 1986, monotypy.

Okinawepipona curcipunctura Nguyen \& Xu, 2014

Okinawepipona kogimai taiwana Yamane, 1987

Okinawepipona nigra Nguyen \& Xu, 2014

\section{Onychopterocheilus Blüthgen, 1955}

Onychopterocheilus Blüthgen, 1955, Mitt. Münch. Entomol. Ges. 44/45: 406, 407.

Type species: "Pterocheilus daw (Dusmet, 1909)" [= Odynerus (Hoplomerus) daw

Dusmet, 1903], monotypy.

Onychopterocheilus (Asiapterocheilus) bensoni (Giordani Soika, 1941)

Onychopterocheilus (Asiapterocheilus) nigropilosus (Kostylev, 1940)

Onychopterocheilus (Asiapterocheilus) rongsharensis (Giordani Soika, 1977)

Onychopterocheilus (Asiapterocheilus) tibetanus (Meade-Waldo, 1913)

Onychopterocheilus (Asiapterocheilus) waltoni (Meade-Waldo, 1913) 
Onychopterocheilus (Onychopterocheilus) chinensis Gusenleitner, 2005

Onychopterocheilus (Onychopterocheilus) dementievi (Kostylev, 1940)

Onychopterocheilus (Onychopterocheilus) eckloni (Morawitz, 1885)

Onychopterocheilus (Onychopterocheilus) wuhaiensis Gusenleitner, 2005

\section{Orancistrocerus van der Vecht, 1963}

Orancistrocerus van der Vecht, 1963, Zool. Verh., Leiden 60: 58 (key), 99, genus. Type species: Odynerus drewseni de Saussure, 1857

Orancistrocerus aterrimus aterrimus (de Saussure, 1852)

Orancistrocerus drewseni drewseni (de Saussure, 1857)

Orancistrocerus drewseni ingens (von Schulthess, 1934)

Orancistrocerus drewseni opulentissimus (Giordani Soika, 1941)

Orancistrocerus moelleri aulicus Giordani Soika, 1973

\section{Oreumenes Bequaert, 1926}

Oreumenes Bequaert, 1926, Ann. S. Afr. Mus. 23: 488. Type species: Eumenes harmandi Perez, 1905 [= Eumenes decoratus Smith, 1852], monotypy.

Oreumenes decoratus (Smith, 1852)

\section{Orientalicesa Koçak \& Kemal, 2010}

Orientalicesa Koçak \& Kemal, 2010, CESA Misc. Pap. 151: 4, replacement name for Kennethia Giordani Soika, 1994, non De Dekker, 1979. Type species: Odynerus unifasciatus von Schulthess, 1934.

Orientalicesa confasciatus Tan \& Carpenter, nom. n.

Replacement name for Orientalicesa unifasciatus (von Schulthess, 1934) (junior primary homonym of Odynerus unifasciatus de Saussure, 1852).

\section{Paraleptomenes Giordani Soika, 1970}

Paraleptomenes Giordani Soika, 1970, Boll. Mus. Civ. Stor. Nat. Venezia 20/21: 79, genus. Type species: Paraleptomenes nurseanus Giordani Soika, 1970, monotypy.

Paraleptomenes kosempoensis (von Schulthess, 1934)

Paraleptomenes miniatus miniatus (de Saussure, 1855)

\section{Parancistrocerus Bequaert, 1925}

Parancistrocerus Bequaert, 1925, Trans. Am. Entomol. Soc. 51: 64. Type species: Odynerus fulvipes de Saussure, 1855 [= O. "Alavipes Fabricius" sensu de Saussure, 1852, non Vespa flavipes Fabricius, 1775].

Parancistrocerus hongkongensis Gusenleitner, 2002

Parancistrocerus intermediatus (Sonan, 1939)

Parancistrocerus kuraruensis (Sonan, 1939)

Parancistrocerus nitobei (Sonan, 1939)

Parancistrocerus taihorinensis (von Schulthess, 1934)

Parancistrocerus taikonus (Sonan, 1939) 
Parancistrocerus yachowensis konkunesis Giordani Soika, 1994

Parancistrocerus yachowensis yachowensis Giordani Soika, 1986

Parancistrocerus yamanei Gusenleitner, 2000

\section{Pararrhynchium de Saussure, 1855}

Pararrhynchium de Saussure, 1855, Ét. Fam. Vesp. 3: 173. Type species: Rhynchium ornatum Smith, 1852, monotypy.

Pararrhynchium ornatum bifasciatulum Giordani Soika, 1986

Pararrhynchium ornatum infrenis Giordani Soika, 1973

Pararrhynchium ornatum multifasciatum Giordani Soika, 1986

Pararrhynchium ornatum ornatum (Smith, 1852)

Pararrhynchium ornatum sauteri (von Schulthess, 1934)

Pararrhynchium paradoxum paradoxum (Gussakovskij, 1932)

Pararrhynchium sinense (von Schulthess, 1913)

Pararrhynchium smithii (de Saussure, 1855)

Pararrhynchium taiwanum Kim \& Yamane, 2007

\section{Pareumenes de Saussure, 1855}

Pareumenes de Saussure, 1855, Ét. Fam. Vesp. 3: 133. Type species: Eumenes quadrispinosus de Saussure, 1855.

Pareumenes (Nortonia) taiwanus (Sonan, 1937)

Pareumenes (Pareumenes) chinensis Liu, 1941

Pareumenes (Pareumenes) obtusus Liu, 1941

Pareumenes (Pareumenes) quadrispinosus acutus Liu, 1941

Pareumenes quadrispinosus conjunctus Liu, 1941

Pareumenes (Pareumenes) quadrispinosus interruptus Liu, 1941

Pareumenes (Pareumenes) quadrispinosus quadrispinosus (de Saussure, 1855)

Pareumenes (Pareumenes) quadrispinosus transitorus Liu, 1941

\section{Parodontodynerus Blüthgen, 1938}

Parodontodynerus Blüthgen, 1938 (1937), Konowia 16: 280. Type species: Eumenes ephippium Klug, 1817.

Parodontodynerus laudatus (Kostylev, 1940)

\section{Phimenes Giordani Soika, 1992}

Phimenes Giordani Soika, 1992, Lavori Soc. Ven. Sci. Nat. 17: 41, 66, genus, replacement name for Phi de Saussure, 1855, non de Saussure, 1854. Type species: Vespa arcuata Fabricius, 1775.

Phimenes flavopictus flavopictus (Blanchard, 1804)

Phimenes flavopictus formosanus (Zimmermann, 1931)

Phimenes sparsipunctatus Gusenleitner, 2002 


\section{Pseudepipona de Saussure, 1856}

Pseudepipona de Saussure, 1856, Ét. Fam. Vesp. 3: 309. Type species: Odynerus herrichii de Saussure, 1856, monotypy.

Pseudepipona (Pseudepipona) augusta (Morawitz, 1867)

Pseudepipona (Pseudepipona) herrichii herrichii (de Saussure, 1856)

Pseudepipona (Pseudepipona) lativentris rubricans Kurzenko, 1976

Pseudepipona przewalskyi (Morawitz, 1885)

\section{Pseudonortonia Giordani Soika, 1936}

Pseudonortonia Giordani Soika, 1936, Ann. Mus. Civ. Stor. Nat. Genova 59: 268, genus. Type species: Odynerus difformis de Saussure, 1853

Pseudonortonia abbreviaticornis Giordani Soika, 1941

\section{Pseudozumia de Saussure, 1875}

Pseudozumia de Saussure, 1875, Smithson. Misc. Coll. 254 (I): 128, division of genus Montezumia de Saussure. Type species: Montezumia indica de Saussure, 1855, monotypy.

Pseudozumia indica indica (de Saussure, 1855)

Pseudozumia indica paulonotata Giordani Soika, 1941

Pseudozumia indosinensis Giordani Soika, 1960

\section{Pseumenes Giordani Soika, 1935}

Pseumenes Giordani Soika, 1935, Ann. Mus. Civ. Stor. Nat. Genova 57: 145. Type species: Eumenes eximius Smith, 1861.

Pseumenes depressus depressus (de Saussure, 1855)

Pseumenes imperatrix (Smith, 1857)

\section{Pterocheilus Klug, 1805}

Pterocheilus Klug, 1805, Beitr. Naturk. 1: 143. Type species: Vespa phalerata Panzer, 1797.

Pterocheilus albofasciatus Smith, 1878

Pterocheilus napalkovi Kurzenko, 1977

\section{Rhynchium Spinola, 1806}

Rhynchium Spinola, 1806, Ins. Ligur. 1: 84. Type species: Rygchium europaeum Spinola, 1806 [= Vespa oculata Fabricius, 1781], monotypy.

Rhynchium brunneum brunneum (Fabricius, 1793)

Rhynchium quinquecinctum quinquecinctum (Fabricius, 1787)

\section{Stenodyneriellus Giordani Soika, 1962}

Stenodyneriellus Giordani Soika, 1962 (1961), Boll. Mus. Civ. Stor. Nat. Venezia 14:

65, 71. Type species: Stenodyneriellus turneriellus Giordani Soika, 1962.

Stenodyneriellus depressus Li \& Chen, 2016 
Stenodyneriellus guttulatus (de Saussure, 1862)

Stenodyneriellus maolanensis Li \& Chen, 2016

Stenodyneriellus similiguttulatus Li \& Chen, 2016

\section{Stenodynerus de Saussure, 1863}

Stenodynerus de Saussure, 1863, Mém. Soc. Phys. Hist. Nat. Genève 17: 228. Type species: Odynerus chinensis de Saussure, 1863.

Stenodynerus baronii Giordani Soika, 1975

Stenodynerus bluethgeni van der Vecht, 1971

Stenodynerus chinensis chinensis (de Saussure, 1863)

Stenodynerus clyppeopictus (Kostylev, 1940)

Stenodynerus copiosus Gusenleitner, 2012

Stenodynerus frauenfeldi (de Saussure, 1867)

Stenodynerus funebris (André, 1884)

Stenodynerus incurvitus Gusenleitner, 2003

Stenodynerus morawitzi Kurzenko, 1977

Stenodynerus morbillosus Giordani Soika, 1979

Stenodynerus nepalensis Giordani Soika, 1985

Stenodynerus ninglangensis $\mathrm{Ma} \& \mathrm{Li}, 2016$

Stenodynerus nudus (Morawitz, 1889)

Stenodynerus pappi luteifasciatus Kim \& Yamane, 2004

Stenodynerus pappi pappi Giordani Soika, 1976

Stenodynerus pullus Gusenleitner, 1981

Stenodynerus reflexus $\mathrm{Ma} \& \mathrm{Li}, 2016$

Stenodynerus similibaronii $\mathrm{Ma} \& \mathrm{Li}, 2016$

Stenodynerus taiwanus Kim \& Yamane, 2004

Stenodynerus tenuilamellatus Ma \& Li, 2016

Stenodynerus tergitus Kim, 1999

\section{Subancistrocerus de Saussure, 1855}

Subancistrocerus de Saussure, 1855, Ét. Fam. Vesp. 3: 206. Type species: Odynerus sichelii de Saussure, 1855.

Subancistrocerus camicrus (Cameron, 1904)

Subancistrocerus compressus Li \& Chen, 2014

Subancistrocerus jinghongensis Li \& Chen, 2014

Subancistrocerus kankauensis (von Schulthess, 1934)

Subancistrocerus sichelii (de Saussure, 1855)

\section{Symmorphus Wesmael, 1836}

Symmorphus Wesmael, 1836, Bull. Acad. R. Belg. 3: 45. Type species: Odynerus elegans

Wesmael, 1833.

Symmorphus ambotretus Cumming, 1989

Symmorphus angustatus (Zetterstedt, 1838) 
Symmorphus apiciornatus (Cameron, 1911)

Symmorphus aurantiopictus Giordani Soika, 1986

Symmorphus bifasciatus (Linnaeus, 1761)

Symmorphus cavatus Li and Chen, 2014

Symmorphus foveolatus Gussakovskij, 1933

Symmorphus fuscipes (Herrich-Schaeffer, 1838)

Symmorphus hoozanensis (von Schulthess, 1934)

Symmorphus lucens (Kostylev, 1938)

Symmorphus mizuhonis Tsuneki, 1977

Symmorphus nigriclypeus Li \& Chen, 2014

Symmorphus ornatus Gusenleitner, 2000

Symmorphus sichuanensis Lee, 1981

Symmorphus sublaevis (Kostylev, 1940)

Symmorphus tianchiensis Li \& Chen, 2014

Symmorphus violaceipennis Giordani Soika, 1966

Symmorphus yananensis Gusenleitner, 2002

Symmorphus yunnanensis Gusenleitner, 2002

\section{Tropidodynerus Blüthgen, 1939}

Tropidodynerus Blüthgen, 1939, Veröff. Deutsch. Kolon. Übersee Mus. Bremen 2:

259, 260. Type species: "Hoplomerus interruptus (Brullé, 1832) $=H$. mandibularis

Morawitz, 1885” [= Polistes interrupta Brullé, 1832].

Tropidodynerus concavus $\mathrm{Li} \&$ Chen, 2015

Tropidodynerus liupanshanensis Li \& Chen, 2015

\section{Zethus Fabricius, 1804}

Zethus Fabricius, 1804, Syst. Piez.: xii, 282. Type species: “Zethus coeruleo-pennis Fab."

[= Vespa coeruleopennis Fabricius, 1798].

Zethus dolosus Bingham, 1897

Zethus malayanus Gusenleitner, 2010

Zethus nanlingensis Nguyen \& Xu, 2017

Zethus taiwanus Yeh \& Lu, 2017

Zehtus velamellatus Tan, 2018

Zethus nigerrimus Gusenleitner, 2001

\section{Acknowledgements}

We wish to thank Mr. Christophe Barthélémy (Hong Kong) and two anonymous reviewers for their comments. The first author wishes to thank Dr. Claire Villemant (MNHN, Paris) for her extremely kind help during her visits in France. The research was supported jointly by the National Natural Science Foundation of China (NSFC, No. 31201732, 31572300), the Research Fund for the Doctoral Program of Higher Education of China 
(No. 20116101120001), the Opening Foundation of Shaanxi Key Laboratory for Animal Conservation, Northwest University, China, and the Richard Gilder Graduate School, American Museum of Natural History (AMNH) collection study grant (No. P305062).

\section{References}

Carpenter JM, Cumming JM (1985) A character analysis of the North American potter wasps (Hymenoptera: Vespidae: Eumeninae). Journal of Natural History 19: 877-916. https:// doi.org/10.1080/00222938500770551

Carpenter JM (1986) A synonymic generic checklist of the Eumeninae (Hymenoptera: Vespidae). Psyche 93: 61-90. https://doi.org/10.1155/1986/12489

Carpenter JM, Garcete-Barrett BR (2003) A key to the Neotropical genera of Eumeninae (Hymenoptera: Vespidae). Boletin del Museo Nacional de Historia Natural del Paraguay 14(1/2): 52-73.

Hermes MG, Melo GAR, Carpenter JM (2014) The higher-level phylogenetic relationships of the Eumeninae (Insecta, Hymenoptera, Vespidae), with emphasis on Eumenes sensu lato. Cladistics 30: 453-484. https://doi.org/10.1111/cla.12059

Lee TS (1981) Remarks on some Vespoidea (Hymenoptera) from Fujian, with description of a new species. Wuyi Science Journal 1: 197-199.

Lee TS (1982a) Hornets from Agricultural reigions of China (Hymenoptera: Vespoidea). Agriculture Publishing House, Beijing, 255 pp.

Lee TS (1982b) On the Vespoidea from Yunnan province, China. Zoological Research 3(1): 83-87.

Lee TS (1985) Economic Insect Fauna of China, 30. Hymenoptera: Vespoidea. Science Press, Beijing, 153 pp. [+ $12 \mathrm{pl}]$.

Li T-J, Chen B (2014a) The taxonomic accounts of the genus Symmorphus Wesmael (Hymenoptera, Vespidae, Eumeninae) from China, with descriptions of three new species. ZooKeys 389: 9-26. https://doi.org/10.3897/zookeys.389.7045

Li T-J, Chen B (2014b) Description of two new Chinese Subancistrocerus de Saussure (Hymenoptera, Vespidae, Eumeninae), with a key to the Chinese species. Journal of Hymenoptera Research 49: 111-127. https://doi.org/10.3897/JHR.49.7487

Li T-J, Chen B (2015) Two new species of the newly recorded subgenus Tropidodynerus Blüthgen (Hymenoptera, Vespidae, Eumeninae) from China, with a key to the known species. Journal of Hymenoptera Research 43: 9-18. https://doi.org/10.3897/JHR.43.4473

Li T-J, Chen B (2016a) Two newly recorded genera Stenodyneriellus and Lissodynerus with three new species from China (Hymenoptera, Vespidae, Eumeninae). Journal of Hymenoptera Research 49: 111-127. https://doi.org/10.3897/JHR.49.7487

Li T-J, Chen B (2016b) The taxonomic study on the genus Apodynerus Giordani Soika (Hymenoptera: Vespidae: Eumeninae) from China, with descriptions of two new species. Entomotaxonomia 2016(2): 143-155.

Liu C-L (1936-37) A bibliographic and synonymic catalogue of the Vespidae of China, with a cross-referring index for the genera and species. Peking Natural History Bulletin 2(2): 91-114.

Liu C-L (1941) Revisional studies of the Vespidae of China I: The genus Pareumenes Saussure, with descriptions of six new species (Hymenoptera: Eumeninae). Notes d'Entomologie Chinoise 8(6): 245-289. 
Ma Z-X, Chen B, Li T-J (2016) A taxonomic account of the genus Stenodynerus from China, with descriptions of five new species (Hymenoptera, Vespidae, Eumeninae). ZooKeys 595: 17-48. https://doi.org/10.3897/zookeys.595.7734

Ma Z-X, Chen B, Li T-J (2017) Four new species of Euodynerus Dalla Torre, 1904 (Hymenoptera: Vespidae: Eumeninae) from China, with a key to the Chinese species. Zootaxa 4300(2): 245-258. https://doi.org/10.11646/zootaxa.4300.2.6

Nguyen LTP, Xu Z-F (2014) Two new species of the genus Okinawepipona Yamane (Hymenoptera: Vespidae: Eumeninae) from Vietnam and China. Zootaxa 3795(1): 38-44. https:// doi.org/10.11646/zootaxa.3795.1.4

Nguyen LTP, Xu Z-F (2015) Taxonomic notes on the genus Gribodia Zavattari, 1912 (Hymenoptera: Vespidae: Eumeninae) from Vietnam and China, with description of a new species. Zootaxa 4040(4): 458-464. https://doi.org/10.11646/zootaxa.4040.4.5

Nguyen LTP, Xu Z-F (2017) First record of the genus Zethus Fabricius, 1804 (Hymenoptera: Vespidae, Eumeninae) from China with description of a new species. Zootaxa 4272(4): 596-600. https://doi.org/10.11646/zootaxa.4272.4.10

Pannure A, Belavadi VV, Carpenter JM (2016) Taxonomic studies on potter wasps (Hymenoptera: Vespidae: Eumeninae) of South India. Zootaxa 4171 (1): 1-50. https://doi. org/10.11646/zootaxa.4171.1.1

Tan J-L, van Achterberg C, Chen X-X (2015) Potentially lethal social wasps, Fauna of the Chinese Vespinae (Hymenoptera: Vespidae). Beijing: Science Press, China, 198 pp.

Tan J-L, Carpenter JM, van Achterberg C (2018a) Most northern Oriental distribution of Zethus Fabricius (Hymenoptera: Vespidae: Eumeninae), with a new species from China. Journal of Hymenopteran Research [accepted, in press].

Tan J-L, van Achterberg C, He YF, Carpenter JM (2018b) Distribution of Northeast Asian Allorhynchium van der Vecht (Hymenoptera: Vespidae), with a key to Oriental species. Zootaxa.

Yamane S, Murota T (2015) A new Anterhynchium species from Japan, with a key to the Northeast Asian species of the genus (Hymenoptera, Eumenidae). Halteres 6: 95-103.

Yamane S (1990) A Revision of the Japanese Eumenidae (Hymenoptera, Vespoidea). Insecta Matsumurana 43: 1-189.

Yeh W-C, Lu S-S (2017) New record of the genus Zethus Fabricius from Taiwan, with the description of $Z$. taiwanus sp. nov. and a key to the species of trimaculatus-group (Hymenoptera: Vespidae: Eumeninae). Zootaxa 4324(3): 529-540. https://doi.org/10.11646/ zootaxa.4324.3.7

You J, Chen B, Li T-J (2013) Two new species of the genus Ancistrocerus Wesmael (Hymenoptera, Vespidae, Eumeninae) from China, with a key to the Oriental species. ZooKeys 303: 77-86. https://doi.org/10.3897/zookeys.303.4922

Zhou X, Chen B, Li T-J (2012) Two new species and a key to species of the genus Eumenes Latreille (Hymenoptera: Vespidae: Eumeninae) from southwestern China. Entomotaxonomia 34(2): 467-474.

Zhou X, Chen B, Li T (2013) Two new species of the genus Discoelius Latreille (Hymenoptera, Vespidae, Eumeninae) from China, with a key to the Chinese species. Journal of Hymenoptera Research 32: 45-54. https://doi.org/10.3897/jhr.32.4958

Zhou X, Chen B, Li T-J (2011) The taxonomic research progress of Eumeninae (Hymenoptera: Vespidae). Journal of Chongqing Normal University (Natural Science) 28(6): 22-29. 
